\title{
An Analysis Study of Features for Hearing Aid Satisfaction Questionnaires: Satisfaction with Amplification in Daily Life, Client Oriented Scale of Improvement, International Outcome Inventory for Hearing Aids
}

\author{
Gungu Kim¹, Eunsung Lee', Dokyun Kim¹, Jinsook Kim,2 \\ 'Department of Speech Pathology and Audiology, Graduate School, Hallym University, Chuncheon, Korea \\ ${ }^{2}$ Division of Speech Pathology and Audiology, Research Institute of Audiology and Speech Pathology, College of Natural Sciences, Hallym University, \\ Chuncheon, Korea
}

보청기 착용 만족도를 측정하는 설문지의 특성 분석 연구: Satisfaction with Amplification in Daily Life, Client Oriented Scale of Improvement, International Outcome Inventory for Hearing Aids

$$
\text { 김건구 }{ }^{1} \cdot \text { 이은성 }{ }^{1} \cdot \text { 김도균 }^{1} \cdot \text { 김진숙,2 }
$$

한림대학교 일반대학원 언어병리청각학과', 한림대학교 자연과학대학 언어청각학부 · 청각언어연구소 ${ }^{2}$

\begin{abstract}
Purpose: This study was aimed to provide translated questionnaires in Korean including Satisfaction with Amplification in Daily Life (SADL), Client Oriented Scale of Improvement (COSI), and International Outcome Inventory for Hearing Aids (IOI-HA) and analyze their reliabilities and validities for measuring and improving hearing-aid satisfaction level in Korea. Methods: Fifty people who were fitted with their new hearing-aids participated (70.4 \pm 12.4$)$. All the participants answered Korean-IOI-HA and newly translated SADL and COSI in Korean to measure hearing aid satisfaction, when they visited the hearing-aid centers where they were fitted hearing-aids initially. The hearing-aid types were Completely In the Canal for 29, In The Canal for 10, and Receiver In the Canal for 11 . Monaural and binaural users were 20 and 30, respectively. Out of fifty, fifteen performed test-retest measurements. Results: Translated SADL, COSI, and IOI-HA's means and Cronbach's alpha values were 4.76 and $0.83,3.60$ and 0.83 , and 3.73 and 0.70 . There was a significant correlation coefficient among three questionnaires. No significant difference according to hearing-aid types was found. A significant difference for the wearing manners between bilateral and unilateral hearing aids was found. The correlations between test and retest were 0.83 for SADL, 0.71 for COSI, and 0.74 for IOI-HI indicating good reliabilities. Conclusion: The translated versions of SADL, COSI and IOI-HA were validated as useful tools for measuring satisfaction of hearing-aids and the fitting in Korea. Using these questionnaires, better satisfaction level of hearing-aids in Korea could be provided in the future.
\end{abstract}

Key Words: Questionnaires, Korean-Satisfaction with Amplification in Daily Life, Korean-Client Oriented Scale of Improvement, Korean-International Outcome Inventory for Hearing Aids, Hearing aid satisfaction.

Received: July 1, 2018 / Revised: July 20, 2018 / Accepted: July 23, 2018

Correspondence: Jinsook Kim, Division of Speech Pathology and Audiology, Research Institute of Audiology and Speech Pathology, College of Natural Sciences, Hallym University, 1 Hallymdaehak-gil, Chuncheon 24252, Korea Tel: +82-33-248-2213 / Fax: +82-33-256-3240 / E-mail: jskim@hallym.ac.kr

\section{INTRODUCTION}

국내에 청각 및 언어장애인으로 등록된 수는 2001년 약 11만 명에서 2016년에는 약 27만 명으로 꾸준하게 증가하고 있다
(Korea Institute for Health and Social Affairs, 2017; Korean Ministry of Employment and Labor, 2015). 더욱이 보건복지 부는 국민건강보험법 적용 범위를 확대하여 보청기 구매에 대 한 보조금을 2015년부터 확대 지급하여 보청기가 필요한 청각 
장애인이 보청기를 착용할 수 있도록 장려하고 있다. 따라서 2005년에는 전체 청각장애인의 $44.7 \%$ 가 보청기를 구매하였지 만, 2008년에는 57.1\%, 2011년에는 60.4\%, 2014년에는 61.8\%로 점차 구매율이 증가하였다. 그러나 2014년 보건복지부 통계에 따르면 보청기 구매자 중 보청기를 지속적으로 착용하는 경우 는 절반에도 미치지 못한다고 보고하고 있는데, '기대에 미치지 못하는 보청기 효과, '불편한 착용감, '부정적인 사회적 인식, '기 기의 저조한 품질' 등이 원인인 것으로 조사되었다(Korea Institute for Health and Social Affairs, 2014; Ministry of Health and Welfare, 2009; Noh, 2007). 이러한 원인들을 제거할 수 있도록 보청기 착용자에 맞춘 적절한 보청기 피팅은 물론 보청 기 착용 후 만족도를 체계적으로 조사하여야 한다. 왜냐하면 이러한 만족도 조사 결과로 보청기 착용 후 발생할 수 있는 불 편한 부분을 자세히 확인하여 보청기를 재피팅하고 재활 과정 을 계획하여 보청기를 효과적으로 사용할 수 있도록 체계적으 로 도와주어야 하기 때문이다. 보청기 착용 후 만족도를 평가 하는 도구로는 다양한 듣기 상황 속에서 보청기로 듣고 이해하 는 능력을 평가하거나 청각장애인이 받는 정서적·사회적 영향 에 대한 내용을 분석하는 설문지 등이 대부분이다.

보청기 만족도를 평가하는 설문지는 다양한 분야를 평가하 는 도구들로 개발되어 있다. 예를 들어 청각장애의 수용 태도 를 평가하는 Sauders \& Cienkowski(1996)에 의해 개발된 Attitudes Toward Loss of Hearing Questionnaire, 보청기 착용 효과를 평가하는 데 사용되는 Cox \& Gilmore(1990)에 의해 개 발된 Profile of Hearing Aid Performance (PHAP), Cox et al. (1991)에 의해 개발된 Profile of Hearing Aid Benefit (PHAB), 청각장애의 장애지수를 평가하는 Newman et al.(1990)에 의해 개발된 Hearing Handicap Inventory for Adults와 Ventry \& Weinstein(1982)에 의해 개발된 Hearing Handicap Inventory for the Elderly, 그리고 국내에서 $\mathrm{Ku} \& \mathrm{Kim}(2010)$ 에 의해 개 발된 상황별 보청기의 효능을 확인하는 Korean Evaluation Scale for Hearing Handicap 등이 있다. 그중 보청기 착용 효 과를 평가하는 $\mathrm{PHAP}$ 와 $\mathrm{PHAB}$ 는 문항 수가 66개로 집중력을 잃지 않고 답하기에 문항 수가 많기 때문에 1998년 22개 문항 으로 축약된 Abbreviated PHAP (APHAP)가 Purdy \& Jerram (1998)에 의해 개발되었고, 1995년 24개 문항으로 축약된 Abbreviated PHAB (APHAB)가 Cox \& Alexander(1995)에 의해 개발되었다. 이후 이렇게 문항이 축약된 설문지가 더 널리 사용 되고 있는데 APHAP은 '의사소통 환경에 따른 일상적인 의사 소통', ‘반향음에서 의사소통, '소음 환경에서의 의사소통', '큰소 리에 대한 불쾌감'의 네 가지 영역에 대한 문항들로 구성되어 청각장애로 인한 어려움의 정도와 보청기 착용에 따른 수행 능 력을 측정할 수 있게 되어 있다. 저자들은 102명을 대상으로
$\mathrm{PHAP}$ 과 $\mathrm{APHAP}$ 을 비교하였는데, 평균 총점은 각각 45.5점과 50.1점이고, 내적 일관성은 각각 0.60 0.94와 0.77 0.86이어서, $\mathrm{APHAP}$ 이 PHAP에 비해 평균 총점에서 만족도가 조금 낮게 나타났고, 내적 일관성은 유사한 것으로 나타나서 APHAP이 PHAP을 대체하기에 적합하다고 보고하였다(Purdy \& Jerram, 1998). APHAB은 '일상적인 의사소통', '반향음에서 의사소통', '소음 환경에서의 의사소통', '큰소리에 대한 불쾌감'의 네 가지 영역을 7점 척도로 평가할 수 있도록 구성되어 있다. 또한 $\mathrm{APHAB}$ 은 보청기 착용 전후에 대한 내용을 추가로 답변하도 록 요구하여, 착용 후 청각장애로 인한 어려움이 얼마나 감소 하였는지 측정할 수 있도록 하였다. 국내에서도 45 명을 대상으 로 보청기 착용 전후의 점수를 비교하여, 일상적인 의사소통, 반 향음에서 의사소통, 소음 환경의 의사소통 항목에서의 보청기 착용 전후 만족도 평균이 유의미하게 증가하였고, 큰소리에 대 한 불쾌감에 대해서는 불만족도가 증가하는 결과를 보였다 (Yun et al., 2000). 그 외 보청기 착용에 따른 만족도를 평가하 는 설문지로는 Gatehouse \& Noble(2004)에 의해 개발된 The Speech, Spatial and Qualities of Hearing Scale (SSQ), Cox \& Alexander(1999)에 의해 개발된 Satisfaction with Amplification in Daily Life (SADL), Dillon et al.(1997)에 의해 개발된 Client Oriented Scale of Improvement (COSI), Cox \& Alexander(2002)에 의해 개발된 International Outcome Inventory for Hearing Aids (IOI-HA) 등이 있다.

설문지들은 개발 목적과 평가 영역이 서로 다르고 결과가 나 타내는 역할과 범위도 달라 보청기 만족에 대한 통합적인 능력 을 분석하기에는 특정 설문지 한 개를 사용하기보다는 여러 개 를 보완적으로 사용하는 방법이 적절한 것으로 알려져 있다 (Han et al., 2015; Stephens, 2002). 또한 여러 설문지들은 장단 점이 있으므로 여러 개의 설문지를 동시에 사용하면 보청기 착 용 만족도나 보청기의 착용 효과를 동시다발적으로 평가하고 효율적인 분석이 가능하여 보청기 재피팅과 재활 계획에 폭넓 게 적용할 수 있다.

특히 보청기 만족도를 평가하는 설문지는 보청기 효과나 수 행 능력을 평가하는 설문지와는 좀 다른 방면을 평가해야 한 다. 예를 들어, 환경에 따른 만족도, 개별적으로 느끼는 만족도, 객관적인 만족도 등 평가해야 할 영역이 넓기도 하고, 특정 부 분을 측정하는 설문 내용을 포함하기도 하여야 한다. 예를 들 어 청각장애 정도와 보청기의 양이 청취로 인한 효과를 언어 적, 공간적, 소리의 질적 영역에서 평가할 수 있도록 고안된 $\mathrm{SSQ}$ 는 50개의 문항으로 구성되어 있고, 한국어로 번역되어 사 용되고 있어 국내 보청기 만족도 평가에 대한 요구를 일부 해 소하고 있다. 그러나 전 세계적으로 널리 사용되고 있는 만족도 평가 설문지는 번역본이 적절치 않아 널리 사용되고 있지 못한 
실정이다(Heo \& Lee, 2009).

세계적으로 보청기 착용 만족도를 평가하는 설문지로 널리 사 용되는 설문지는 SADL, COSI, IOI-HA 등이 있다. 이 세 설문 지의 특성, 문항 수, 척도 및 평가 방법을 정리하면 다음과 같다.

SADL (Cox \& Alexander, 1999)

\section{특 성}

'긍정적 효과', '부정적 측면', '서비스 및 비용적 측면', '개인적 이미지'의 네 가지 범주화로 보청기에 대한 구체적이고 다각적 인 평가 가능.

보청기에 초점을 두어 청각장애인의 심리와 주관적 만족도 측정 불가능.

문항 수

총 문항 수는 15 문항으로 ‘긍정적 효과' 6 문항, '부정적 측면' 3문항, '서비스 및 비용적 측면' 3 문항, '개인적 이미지' 3문항임.

\section{척도 및 평가 방법}

7점 척도로 1점부터 7점까지 배점하고 점수가 높을수록 보청 기 만족도 높음.

\section{COSI (Dillon et al., 1997)}

\section{특 성}

인터뷰 형식으로 보청기 착용 후 향상시키고 싶은 듣기 상황 을 제시된 16 개 상황 중에서 스스로 선택하는 상황별 주관적 보청기 만족도 평가.

난이도가 높아 아동이나 노인에게 적용하기는 어렵고 일반 적인 보청기 중심의 만족도를 제시하지는 못함.

\section{문항 수}

16 개 듣기 상황 제시.

두 가지 질문:

(1) 전반적인 청력 향상 정도(improvement)

(2) 보청기 착용 후 최종적 청력 변화(final ability)

\section{척도 및 평가 방법}

1 차와 2 차 검사로 두 차례 평가함.

1 차 검사에서 참가자가 보청기 착용 후 향상하고 싶은 다섯 상황을 서열화하고 2차 검사에서 두 가지 질문 (1)과 (2)에 5점 척도로 답변하도록 구성되어 있음.

점수가 높을수록 좋은 보청기 만족도를 의미함.
IOI-HA (Cox \& Alexander, 2002)

특 성

국제적 비교가 가능하도록 짧고 간단한 평가 도구로 구성.

2주간의 보청기 착용 경험을 토대로 보청기의 기능적 측면과 개인의 만족도를 간략하게 측정.

문항 수가 적고 내용이 간단하기 때문에 설문지 작성에 걸리 는 시간이 짧고 국제적으로 공통된 내용을 비교하기에 용이하 지만, 보청기의 듣기 상황별 효과나 보청기 착용 후 구체적이고 다양한 만족도를 평가하기에 어려움이 있음.

\section{문항 수}

총 7개 문항.

\section{척도 및 평가 방법}

5점 척도로 구성되어 있고 점수가 높을수록 보청기 만족도 가 높은 것을 의미함.

‘보청기 착용 후 만족 요인'과 ‘보청기 착용 후 제한 요인’ 등 두 가지 요인을 측정.

이들 중 SADL은 전반적인 보청기 착용 만족도를 측정하는 자가진단 도구로 개발되었다(Cox \& Alexander, 1999). 저자들 은 196명을 대상으로 검사하여, 0.82 라는 높은 내적 일관성을 바탕으로 설문지의 신뢰도와 타당도를 검증하였다(Cox \& Alexander, 2001). 국내에서는 번역본이 제작되어 42 명을 대상으 로 연구하였는데 전체 환자군에서 SADL 항목별 점수가 원저 자들이 제시한 잠정적 기준인 20 80\%(4.3 5.6점)에 비해 4.28 점으로 조금 낮게 나타났다(Lee et al., 2004). 더욱이 이 번역 본의 내적 일관성은 검증되지 않았고, 원본과 비교할 때 한국 어 표현이 부적절한 부분이 여러 곳 있으며, 원본에 없는 내용 이나 불필요한 문장이 추가되었고, 원본 문장이 누락되기도 하 여 이 연구에서 제작된 번역본을 그대로 사용하기에 무리가 있 다. 예를 들어 'Do you think your hearing aid(s) is worth the trouble?'은 ‘당신은 보청기 착용을 위해 수차례 병원을 방문하 고, 검사 및 맞춤 과정을 진행했습니다. 당신의 보청기가 그만 한 가치가 있다고 생각하십니까?'로 번역되어 원본에 없는 내용 이 추가되었고, 'How competent was the person who provided you with your hearing aid(s)?'는 '당신에게 보청기를 제공한 사람(이비인후과 의사나 보청기 기사)이 적절하게 보청기를 제 공했다고 생각하십니까?'로 번역되어 원본에서는 보청기 제공 자에 대한 전문성을 질문하였으나 번역본은 적절한 보청기의 제공 여부를 질문하는 문항으로 변형되었다. 또한 번역본의 설 문 순서를 원본과 달리 네 개의 범주별로 재배열하여, 원본에 
서 제시된 역전된(reversed) 문항 $(2,4,7,13$ 번)의 배점을 거꾸 로 적용할 수 없도록 구성하여 번역본의 배점이 애매하고 원본 과 결과를 비교하기에 혼란스럽게 구성되어 있다. 따라서 $\mathrm{SADL}$ 을 국내에서 사용하고 국외 자료와 비교 분석하려면 번 역본을 재작성하고 국내 보청기 착용자를 대상으로 검사하여 신뢰도와 타당도를 검증하는 과정이 필요할 것으로 생각된다. 1997년 호주의 National Acoustic Laboratories에서 개발된 $\mathrm{COSI}$ 의 원저자들은 4,421명을 대상으로 설문지를 시행하여 크 론바흐 알파 값 $0.76 ~ 0.83$ 으로 높은 내적 일관성을 확인하여 보 청기 만족도에 활용될 가능성을 제시하였다(Dillon et al., 1999). 그러나 COSI는 아직까지 국내에서 활용할 수 있는 적절한 번역 본이 없어 국내에서 임상적 적용이나 연구가 이루어지지 못하 고 있다.

IOI-HA는 현재 총 30 개의 언어로 번역되어 원저자의 포털 사이트(https://icra-audiology.org/Repository/self-report-repository/Survey)에 제시되어 있는데 그중 한국어 버전은 2004 년 김진숙이 번역 후 업로드하여 누구든지 사용할 수 있도록 되 어 있다(https://icra-audiology.org/Repository/self-report-repository/IOI-HAquestionnaires/korean) (Appendix 1). 국문 으로 번역된 IOI-HA를 Korean (K)-IOI-HA라 명명하여 이에 대한 타당도와 신뢰도를 분석한 국내 연구 결과는 크론바흐 알 파 값 0.83 이라는 높은 내적 일관성을 보였고 검사-재검사에서 0.94의 높은 상관계수를 보여 보청기 사용 만족도를 조사할 수 있는 번역본으로 사용할 수 있도록 검증이 되었다(Chu et al., 2012). 또 다른 국내 연구 결과에서도 K-IOI-HA가 사용되었는 데, 106명을 대상으로 평가하여 보청기 착용 후 만족과 제한 요 인인 factor 1,2 의 내적 일관성은 0.83 과 0.86 이고, 검사-재검 사 상관계수는 0.89 로 높은 신뢰도를 보였다(Lee et al., 2005). 그 외 여러 나라에서도 IOI-HA가 조사되었다. 포르투갈어로 번 역된 IOI-HA 연구는 2017년 80명을 대상으로 시행하여, 총점 평균 27.33점, 문항별 평균 3.19 4.54점, 내적 일관성 0.83 등을 보였다(Paiva et al., 2017). 스웨덴어로 번역된 IOI-HA는 2012년 부터 2016년까지 106,631명을 대상으로 평가하여, 평균 총점 26.79점, 문항별 평균 3.31 4.10점, 내적 일관성 0.81로 나타났고 (Arlinger et al., 2017), 덴마크어로 번역된 IOI-HA는 341명을 대 상으로 시행하여 문항별 평균 3.52 4.59점, 내적 일관성 0.82 , 검 사-재검사는 0.75 의 높은 상관계수를 나타냈다(Thunberg Jespersen et al., 2014). 네덜란드어로 번역된 IOI-HA는 505명을 대 상으로 검사하여 평균 총점 25.45점, 문항별 평균 3.19 4.34점, factor 1 과 2 의 내적 일관성은 0.77 과 0.78 , 검사-재검사는 0.73 의 상관계수를 나타냈다(Kramer et al., 2002). 이 세 가지 설문지는 보청기 만족도를 조사하는 대표적인 설문지이지만 각각의 특성 이 다르므로, 보청기 만족도를 다각적으로 분석하기 위하여 세
개의 설문지를 함께 사용하면 효율적일 것으로 생각된다. 국내 에서는 기존의 K-IOI-HA는 그대로 사용하고, 국내 번역본이 부적절한 SADL의 번역본을 재정비하고, COSI는 새로이 번역 본을 작성하여 사용할 수 있을 것으로 생각된다.

따라서 본 연구는 다음과 같은 다섯 가지 연구 문제를 분석 하여 국내에서 보청기 만족도 평가의 범위를 확대하고 보청기 만족도의 실태를 정확하게 분석하여 국내 보청기 착용자의 만 족도에 대한 폭넓고 체계적인 평가를 통해 보청기 착용에 대한 불편 요소를 확인하고 개선하여 국내 보청기 만족도를 향상시 키고자 한다. 1) 국제적으로 신뢰도와 타당도가 검증된 설문지 인 SADL의 번역본을 재정비하고 COSI의 한국어 번역본을 제 작하고자 한다. 2) 1)에서 번역본으로 정리된 SADL과 COSI를 $\mathrm{K}-\mathrm{IOI}-\mathrm{HA}$ 와 함께 적용하여 국내의 보청기 만족도를 다각적 으로 분석하고자 한다. 3) 각 설문지에 대한 신뢰도와 상관성을 분석하여 번역본이 실질적으로 국내에서 사용 가능한 설문지 인지를 확인하고자 한다. 4) 이들 설문지를 이용하여 국내 보청 기 만족도 평가에 적용 가능성을 분석하여 보청기 만족도의 측정 범위와 내용을 확인하고자 한다. 5) 각 설문지에 대한 만 족도 평가가 서로 관련 있는지를 분석하여 평가 내용과 범위에 대해 점검하고 세 개 설문지를 함께 사용할 수 있는지를 확인 하고 그 유용성을 확인하고자 한다.

\section{MATERIALS AND METHODS}

\section{연구 대상}

본 연구는 2015년 7월부터 2016년 5월까지 50명(남성 33명, 여성 17명)의 보청기를 착용하기 시작한 지 1 2개월 된 신규 보청기 착용자 보청기 만족도 검사를 실시하였고, 그중 15 명을 대상으로 검사-재검사 신뢰도를 분석하였다. 연구 참여자의 연 령 범위는 33 89세로, 60대 미만 6명, 60대 12명, 70대 20명, 80 대 12 명이었으며, 평균 연령은 70.4세(표준편차 \pm 12.4 세)였다. 착용한 보청기 유형은 고막형(Completely In the Canal, CIC)이 29명, 외이도형(In The Canal, ITC)이 10명, 개방형(Receiver In the Canal, RIC)이 11명이었고, 편측과 양측 착용자는 각각 20 명과 30 명이었다.

\section{설문지의 구성 및 번역: $\mathrm{K}-\mathrm{SADL}$}

본 연구를 위해 SADL과 COSI의 원저자인 Robyn Cox와 Harvey Dillon에게 이메일로 동의를 구했고 2015년 6월 16일에 이메일로 원저자들의 동의를 받아 한국어 번역본을 제작하였 다. 번역본이 국내 보청기 사용자의 만족도를 적절히 분석하고 원본 연구 자료와 비교할 수 있도록 번역-역번역 절차를 거쳐 번 역본 가안을 작성하였다. 이를 임상 경력 5년 이상의 청능사 2 명 
에게 임상적 적용의 용이성을 확인하고 그 의견을 반영하여 수 정하고 원문을 최대한 반영하면서 국내 보청기 사용자에게 실질 적으로 적용할 수 있도록 정리하여 Korean (K)-SADL과 Korean $(\mathrm{K})-\mathrm{COSI}$ 로 최종 번역본을 완성하였다(Appendix 2, 3).

$\mathrm{K}-\mathrm{SADL}$ 의 구성은 네 가지 범주, 긍정적 효과 6 문항 $(1,3,5$, $6,7,10$ 번), 부정적 측면 3 문항( $2,7,11$ 번), 서비스 및 비용적 측 면 3문항(12,14, 15번), 개인적 이미지 3문항(4, 8, 13번), 총 15 문항으로 이루어져 있고, 각 설문에 대하여 각 문항당 7점 척도 로 1점부터 7점까지 배점하도록 구성되었고 점수가 높을수록 보청기 만족도가 높은 것을 의미한다. 총 문항 중 네 개의 문항 (2, 4, 7, 13번)은 원본대로 역전된(reversed) 문항으로 구성하여 배점을 거꾸로 적용할 수 있도록 하였고, 문항과 범주의 배열은 원본과 동일하게 구성하였다. 실질적인 다음과 같은 문항의 문 제점을 확인하여 평가 분석에 반영하였다. 참여자가 직접 보청 기 구매에 돈을 지불하지 않은 경우, 14 번 문항인 "보청기 가격 은 적당하다고 생각하십니까에 답을 할 수 없으므로 점수 산정 에서 제외하였고, 서비스 및 비용적 측면의 범주에서도 14번 점 수를 제외하였다. 참여자가 보청기를 착용하지 않아도 통화에 어려움이 없거나 편측성 난청일 경우 부정적 측면 범주에 속하 는 11 번 문항인 '대부분의 전화통화에서 보청기가 얼마나 도움 이 된다고 생각하십니까?’라는 문항은 부연 설명 문항인 '보청기 를 사용하지 않고도 전화통화를 잘 하시면 여기에 체크하세요' 에 체크할 경우 이 문항의 점수도 제외하였다. 또한 15 번 문항인 "보청기의 내구성(고장이 나서 수리를 필요로 하는 횟수의 정도) 은 어느 정도 마음에 드십니까?'는 신규 보청기 착용자에게 적절 한 문항이 아니어서 이 문항도 점수 산정에서 제외하였다.

\section{설문지의 구성 및 번역: $\mathrm{K}-\mathrm{COSI}$}

K-COSI는 개방형 설문으로 두 단계로 진행하도록 구성되어 있다. 첫 번째 단계는 초기 재활 시 특정 듣기 상황을 선택하는 과정으로 16 개 상황, '조용한 곳에서 한두 명과 대화 상황', '시 끄러운 곳에서 한두 명과 대화 상황, '조용한 곳에서 그룹으로 대화 상황', '시끄러운 곳에서 그룹으로 대화 상황', '보통 크기의 혹은 라디오 소리 듣기 상황, '친한 사람과의 전화통화 상황', '낮선 사람과의 전화통화 상황', '다른 방에서 들리는 핸드폰 소 리 듣기 상황', '벨 소리 혹은 노크 소리 듣기 상황', 자동차 소리 듣고 구별하기 상황, '사교모임에 참여 빈도수 증가 정도', '당황 스럽거나 스스로 바보 같다고 느끼는 정도', '소외된다고 느끼는 정도' '화가 난다고 느끼는 정도', '종교모임이나 대규모 모임 상 황, '기타 상황' 중 대상자가 더 잘 듣고 싶은 구체적인 다섯 가 지 상황을 선택하고 순위를 기록하도록 구성하였다. 두 번째 단 계는 전체적인 청력 향상 정도 및 보청기 착용 후 청력 변화를 평가하는 단계로, 첫 번째 단계에서 선택했던 구체적 상황에
대하여 5점 척도로 '악화되었다', '차이가 없다', '조금 좋아졌다', '좋아졌다' '횔씬 좋아졌다' 중 하나를 선택하도록 하여 전체적 인 청력 향상의 정도를 평가하도록 하였다. 최종적으로 보청기 를 착용한 후 각각의 구체적 상황에 대한 청력 변화의 정도를 질문하여 5점 척도로 '거의 들을 수 없다', '때때로 들을 수 있 다', '절반 정도 들을 수 있다', '대부분 들을 수 있다, '거의 항상 들을 수 있다' 중 하나를 선택하도록 하였다. 11 14번 상황 범 주를 선택한 경우는 한국어로 번역할 때 문맥상 이해가 쉽도록 괄호 안의 답변 형식인 '거의 그렇지 않다', '때때로 그렇다', '절 반 정도 그렇다', '대부분 그렇다', '거의 항상 그렇다'로 답변하도 록 하여 나온 점수를 서열화하여 평가하였다.

\section{설문지의 구성 및 번역: $\mathrm{K}-\mid \mathrm{OI}-\mathrm{HA}$}

$\mathrm{K}-\mathrm{IOI}-\mathrm{HA}$ 는 보청기 하루 착용 시간(daily use, USE), 보청 기 착용 효과(benefit, $\mathrm{BEN}$ ), 보청기 착용 시 활동의 제한 정도 (residual activity limitations, RAL), 만족도(satisfaction, SAT), 보청기 착용 시 사회적 참여의 방해 정도(residual participation restrictions, RPR), 주변 사람들에게 주는 영향(impact on others, IOTH), 삶의 질(quality of life, QOL)의 7문항으로 구성되어 있다. 두 개의 요인 평가는 보청기 착용 후의 만족 요 인을 평가하는 factor $1(1,2,4,7$ 번)과 보청기 착용 후의 제한 요인을 평가하는 factor $2(3,5,6$ 번)로 구성되어 있으며, 문항당 5점 척도로 1점부터 5점까지 배점하도록 하였고 응답 결과는 점수가 높을수록 보청기 착용 만족도가 높다는 것을 의미한다.

\section{연구 절차}

참가자들은 설문지 및 연구 절차에 대한 안내를 받은 후 동 의서를 작성하였다. 그 후, 네 개의 주파수, $500,1,000,2,000$, $4,000 \mathrm{~Hz}$ 에서 순음 청력 검사, 고막 운동성 검사를 실시한 후 단어 인지도 검사를 실시하였다. 고막 운동성 검사에서 비정상 소견을 보인 경우는 대상에서 제외하여 감각신경성 난청인 경 우만을 대상으로 하였다. 설문지 검사는 연구 참여자가 보청기 를 처음 착용한 센터에서 네 차례에 걸쳐 진행하였으며, 보청기 적응 정도에 따라 최대 여섯 차례까지도 진행하였다. 1 차 방문 시 순음 청력 검사, 고막 운동성 검사, 단어 인지도 검사 등으 로 청력검사를 실시한 후 보청기 착용 상담에서 신규 착용자로 확정된 경우 $\mathrm{K}-\mathrm{COSI} 1$ 차 평가를 실시하였다. 최소 3 주간의 보 청기 적응 기간을 거친 후 2 차 방문 시 $\mathrm{K}-\mathrm{COSI} 2$ 차 평가와 $\mathrm{K}-$ $\mathrm{SADL}$ 과 $\mathrm{K}-\mathrm{IOI}-\mathrm{HA}$ 를 작성하였다. 만일 보청기 착용에 아직 적응되지 않은 경우는 2차 방문에서 $\mathrm{K}-\mathrm{IOI}-\mathrm{HA}$ 만 실시하였고 3 차 방문 때 $\mathrm{K}-\mathrm{COSI} 2$ 차 평가와 $\mathrm{K}-\mathrm{SADL}$ 을 진행하였다. 검 사-재검사는 일차적으로 모든 평가가 끝난 후 최소 3 주의 시간 이 지난 시점 이후 설문지를 작성하였다. 
설문지 작성은 대면과 서면으로 진행하였을 때 결과의 차이 가 나지 않는다는 선행연구(Shin, 2011)의 결과를 참조하여 대면 과 서면 방법 중 참여자가 편한 방법을 선택하였다. 일반적으로 $\mathrm{K}-\mathrm{COSI}$ 는 내용에 대한 이해가 쉽지 않았으므로 주로 대면으로, $\mathrm{K}-\mathrm{IOI}-\mathrm{HA}$ 는 짧고 간단하여 서면으로, $\mathrm{K}-\mathrm{SADL}$ 은 참여자의 상 태에 따라 대면과 서면 방법을 혼합하여 실시하였다.

\section{통계 분석}

통계적 분석은 SPSS 소프트웨어(version 21.0; IBM Corp., Armonk, NY, USA)를 이용하였다. 세 설문지의 각 문항과 범 주의 내적 일관성을 확인하기 위해 크론바흐 알파(Cronbach's alpha) 값을 분석하였다. 세 설문지의 평균점수와 보청기 유형과 착용 형태에 따른 차이를 분석하기 위해 반복 측정된 일원배치 분산분석(one-way ANOVA with repeated measure)을 이용하 였고, 유의수준 0.05 를 기준으로 분석하였다. K-COSI와 K-IOI$\mathrm{HA}$ 의 상관도 측정에는 켄달의 타우(Kendall's tau) 검정법을 이 용하여 분석하였다. 검사-재검사 간 상관관계 측정을 위해 Pearson 상관성 분석을 시행하였다.

\section{RESULTS}

\section{$\mathrm{K}-\mathrm{SADL}$ 분석}

$\mathrm{K}-\mathrm{SADL}$ 의 각 문항과 네 개의 범주에 따른 평균, 표준편차, 크론바흐 알파 값을 분석하였을 때, 전체 문항에 대한 총 평균 점수는 4.76점이고, 네 개 범주의 평균점수는 긍정적 효과’는 4.83점, '부정적 측면'은 4.92점, '서비스 및 비용적 측면'은 4.40
점, '개인적 이미지'는 4.83점이었다(Table 1). 범주별로 가장 높 은 점수를 나타낸 문항은 $6,7,12,13$ 번 문항이었다. 범주별 크 론바흐 알파 값은 '긍정적 효과'는 0.75 , '부정적 측면'은 0.64 , '서 비스 및 비용적 측면'은 0.55 , '개인적 이미지'는 0.29 였고 총 문 항의 크론바흐 알파 값은 0.83 이었다.

Table 1. Average scores and values of Cronbach's alpha of Korean-Satisfaction with Amplification in Daily Life Items

\begin{tabular}{ccccc}
\hline Subscale & Item & Mean & SD & $\begin{array}{c}\text { Cronbach's } \\
\text { alpha }\end{array}$ \\
\hline Positive effect & Q1 & 4.90 & 1.43 & 0.68 \\
& Q3 & 4.44 & 2.04 & 0.85 \\
& Q5 & 4.90 & 1.36 & 0.67 \\
& Q6 & 5.10 & 1.72 & 0.67 \\
& Q9 & 4.94 & 1.36 & 0.70 \\
Total & Q10 & 4.72 & 1.16 & 0.72 \\
Negative features & Q2 & 4.83 & 1.03 & 0.75 \\
& Q7 & 5.76 & 1.42 & 0.44 \\
Total & Q11 & 4.56 & 1.65 & 0.60 \\
& & 4.92 & 1.27 & 0.26 \\
Service \& cost & Q12 & 5.94 & 0.87 & 0.64 \\
& Q14 & 3.04 & 1.68 & 0.26 \\
& Q15 & 4.11 & 1.69 & 0.52 \\
Total & & 4.40 & 1.09 & 0.55 \\
& Q4 & 4.82 & 1.83 & 0.29 \\
& Q8 & 4.40 & 1.74 & 0.04 \\
& Q13 & 5.28 & 1.78 & 0.17 \\
& & 4.83 & 1.15 & 0.29 \\
\hline
\end{tabular}

SD: standard deviation
Figure 1. Distribution of scores according to four subscales of Korean-Satisfaction with Amplification in Daily Life.
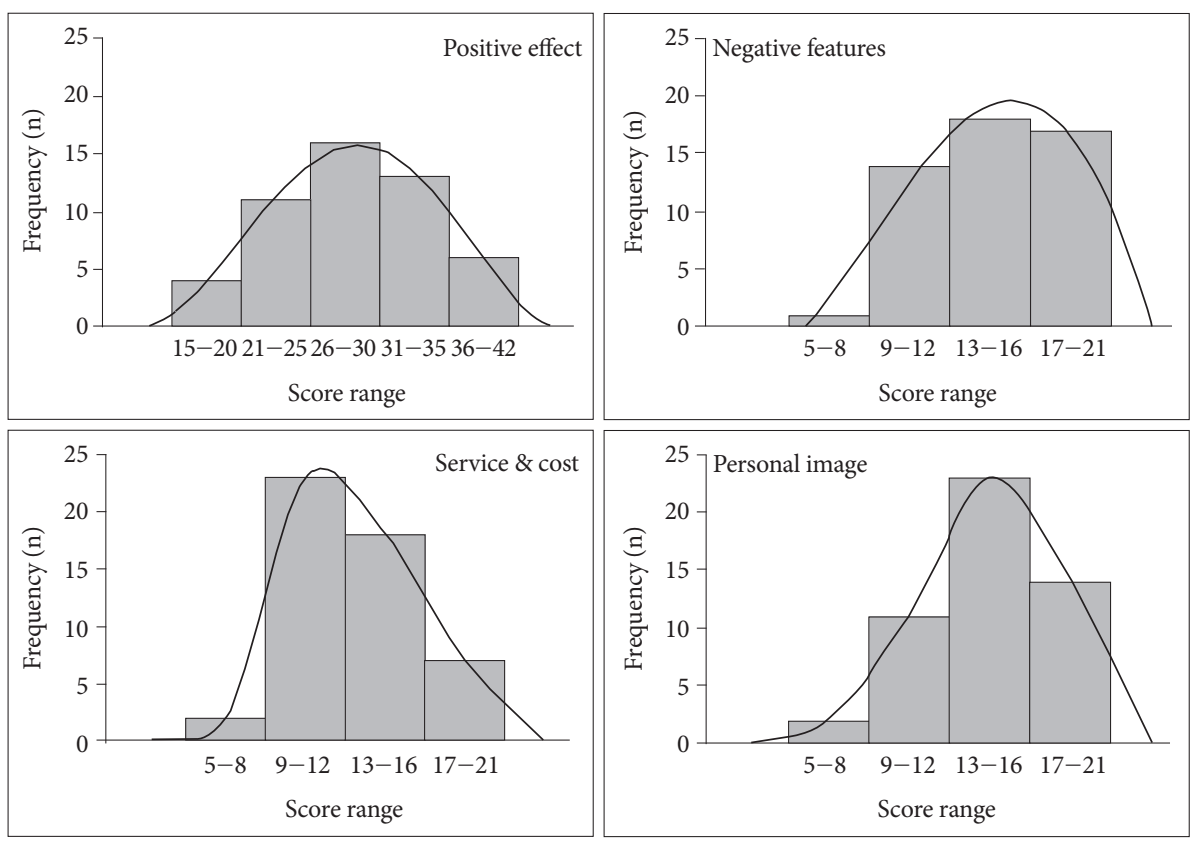
Table 2. Average scores and correlation coefficient between test and retest of Korean-Satisfaction with Amplification in Daily Life

\begin{tabular}{|c|c|c|c|c|c|c|}
\hline \multirow{2}{*}{ Subscale } & \multirow{2}{*}{ Item } & \multicolumn{2}{|c|}{ Test } & \multicolumn{2}{|c|}{ Retest } & \multirow{2}{*}{ Correlation coefficient } \\
\hline & & Mean & $\mathrm{SD}$ & Mean & SD & \\
\hline \multirow[t]{6}{*}{ Positive effect } & Q1 & 4.53 & 1.13 & 5.13 & 0.64 & $0.69^{*}$ \\
\hline & Q3 & 4.40 & 2.16 & 5.20 & 0.94 & \\
\hline & Q5 & 4.60 & 1.45 & 4.33 & 0.90 & \\
\hline & Q6 & 5.00 & 1.36 & 5.00 & 0.93 & \\
\hline & Q9 & 4.07 & 1.53 & 4.33 & 1.11 & \\
\hline & Q10 & 4.40 & 1.18 & 4.27 & 0.96 & \\
\hline \multicolumn{2}{|c|}{ Total } & 4.50 & 0.87 & 4.71 & 0.56 & \\
\hline \multirow[t]{3}{*}{ Negative features } & Q2 & 4.60 & 1.55 & 5.07 & 0.88 & $0.71^{*}$ \\
\hline & Q7 & 5.20 & 1.32 & 5.47 & 1.19 & \\
\hline & Q11 & 4.13 & 0.99 & 4.27 & 0.70 & \\
\hline \multicolumn{2}{|c|}{ Total } & 4.64 & 0.92 & 4.71 & 0.67 & \\
\hline \multirow[t]{3}{*}{ Service \& cost } & Q12 & 5.47 & 0.74 & 5.40 & 0.51 & 0.44 \\
\hline & Q14 & 2.00 & 1.13 & 2.40 & 1.06 & \\
\hline & Q15 & 3.00 & 1.20 & 3.40 & 1.35 & \\
\hline \multicolumn{2}{|c|}{ Total } & 3.49 & 0.69 & 3.73 & 0.76 & \\
\hline \multirow[t]{3}{*}{ Personal image } & Q4 & 5.07 & 1.58 & 4.60 & 0.99 & 0.36 \\
\hline & Q8 & 3.40 & 1.12 & 3.27 & 1.22 & \\
\hline & Q13 & 5.93 & 1.03 & 5.73 & 0.80 & \\
\hline \multicolumn{2}{|c|}{ Total } & 4.80 & 0.76 & 4.53 & 0.65 & \\
\hline
\end{tabular}

${ }^{*} p<0.01$. SD: standard deviation

네 가지 범주별 점수 중 ‘긍정적 효과’는 6문항으로 구성되어 총 15 42점까지의 점수 분포를 보였고, 그 외 세 가지의 범주 는 모두 3문항으로 구성되어 총 5 21점의 점수 분포를 보였다 (Figure 1). 범주별 총 점수의 범위에 따라 점수 분포는 긍정적 효과'는 다섯 개로, 나머지 세 개 범주는 네 개 범위로 나누어 범주별 점수 분포도를 분석하였을 때, 네 범주 모두 정상 분포 곡선의 형태를 나타냈다. 평균점수가 가장 낮게 측정되었던 '서 비스 및 비용적 측면'은 '부정적 측면'과 '개인적 이미지'에 비해 낮은 점수 범위인 9 12점에 속한 경우가 가장 많았던 것으로 나타났다.

$\mathrm{K}-\mathrm{SADL}$ 의 검사와 재검사의 상관계수는 0.83 이고 네 가지 범주 모두 양의 상관관계로 검사-재검사의 신뢰도가 높은 것 으로 나타났다(Table 2).

\section{$\mathrm{K}-\cos$ 분석}

$\mathrm{K}-\mathrm{COSI}$ 의 각 문항과 두 개의 범주에 따른 평균, 표준편차, 크론바흐 알파 값을 분석하였을 때, 전체 문항에 대한 총 평균 점수는 3.6점이고 '전체적인 청력 향상'의 평균점수는 3.61점, '최종적 청력 변화의 평균점수는 3.58점이었다. 총 문항의 크론 바흐 알파 값은 0.83 이고, '전체적인 청력 향상'과 '최종적 청력 변화에서 0.68 의 크론바흐 알파 값이 나타났다(Table 3).

가장 많이 선택한 상황 범주는 5번 “보통 크기의 TV 혹은 라 디오 소리 듣기 상황'이 34회로 보청기 착용 후 가장 향상하고
Table 3. Average scores and values of Cronbach's alpha of Korean-Client Oriented Scale of Improvement items

\begin{tabular}{ccccc}
\hline Measure & Item & Mean & SD & $\begin{array}{c}\text { Cronbach's } \\
\text { alpha }\end{array}$ \\
\hline Improvement & Q1-1 & 3.67 & 0.85 & 0.43 \\
& Q2-1 & 3.48 & 0.83 & 0.61 \\
& Q3-1 & 3.52 & 0.92 & 0.68 \\
& Q4-1 & 3.40 & 0.83 & 0.55 \\
& Q5-1 & 3.81 & 1.06 & 0.40 \\
Final ability & & 3.61 & 0.59 & 0.68 \\
& Q1-2 & 3.52 & 0.71 & 0.49 \\
& Q2-2 & 3.45 & 0.94 & 0.60 \\
& Q3-2 & 3.43 & 1.02 & 0.65 \\
& Q4-2 & 3.29 & 0.97 & 0.60 \\
& Q5-2 & 3.79 & 1.05 & 0.30 \\
Total & & 3.58 & 0.60 & 0.68 \\
\hline
\end{tabular}

SD: standard deviation

싶은 상황으로 조사되었고, 그 다음은 1 번 '조용한 곳에서 한 두 명과 대화 상황이 31회, 2번 시끄러운 곳에서 한두 명과 대 화 상황, 3 번 '조용한 곳에서 그룹으로 대화 상황', 4번 '시끄러 운 곳에서 그룹으로 대화 상황'이 각각 21회 선택되었다. 그 외 10 회 이상 선택한 경우는 7번 '낮선 사람과의 전화통화 상황’이 18회, 9번 '벨 소리 혹은 노크 소리 듣기 상황'이 17회, 15번 '종 교모임이나 대규모 모임 상황이 15 회였다. 그러나 순위별 선택 은 조금 다르게 나타났다. 1 순위는 1 번이 가장 많은 17 명의 착 
용자가 선택하였고, 2순위는 3번이 10명, 3순위는 5번이 13명, 4 순위는 4번이 7명, 5순위에서 9번이 12명으로 상황별 선택 순 위가 나타났다(Table 4).

$\mathrm{K}-\mathrm{COSI}$ 의 검사와 재검사의 상관계수는 0.71 이고 두 가지 측 정 범주인 “보청기 착용 후 전체적인 청력 향상의 정도'와 “보청 기 착용 후 최종적 청력 변화에서 모두 양의 상관관계로 검사재검사의 신뢰도가 높은 것으로 나타났다(Table 5).

\section{$\mathrm{K}-\mathrm{IOI}-\mathrm{HA}$ 분석}

$\mathrm{K}-\mathrm{IOI}-\mathrm{HA}$ 의 각 문항과 두 개의 요인에 따른 평균, 표준편 차, 크론바흐 알파 값을 분석하였을 때, 전체 문항에 대한 총
평균점수는 3.73점이고, 보청기 착용 후 만족 요인인 factor 1 의 평균점수는 3.82점, 보청기 착용 후 제한 요인인 factor 2의 평 균점수는 3.64점으로 나타났다. 각 요인별로 가장 높은 점수를 나타낸 문항은 factor 1 에서 1 번 문항, factor 2 에서 6 번 문항으 로 나타났다. 또한 총 문항의 크론바흐 알파 값은 0.70 이고, factor 1 과 2는 각각 0.76 과 0.22 로 나타났다(Table 6).

$\mathrm{K}-\mathrm{IOI}-\mathrm{HA}$ 의 문항별 점수 분포도를 분석하였을 때, 가장 많 이 5점으로 선택한 문항은 1 번인 'USE'여서 보청기 착용 시간 이 많아진 것으로 나타났고, 가장 적게 5점을 선택한 문항은 3번 인 'RAL'이어서 보청기 착용 시 활동의 제한은 그리 크지 않은 것으로 나타났다. 반대로 1점을 가장 많이 선택한 문항은 5 번인

Table 4. Number of selected categories

\begin{tabular}{|c|c|c|c|c|c|c|c|}
\hline Categories & 1 st & 2 nd & $3 \mathrm{rd}$ & 4 th & 5 th & Total & Order \\
\hline 1. Conversation with 1 or 2 in quiet & $17^{\dagger}$ & 4 & 2 & 6 & 2 & 31 & 2 \\
\hline 2. Conversation with 1 or 2 in noise & 5 & $7^{\dagger}$ & 3 & 3 & 3 & 21 & 3 \\
\hline 3. Conversation with group in quiet & 5 & $10^{\dagger}$ & 3 & 2 & 1 & 21 & 3 \\
\hline 4. Conversation with group in noise & 5 & 5 & 1 & $7^{\dagger}$ & 3 & 21 & 3 \\
\hline 5. Television/radio@ normal volume & 5 & 7 & $13^{\dagger}$ & 6 & 3 & 34 & 1 \\
\hline 6. Familiar speaker on phone & 2 & 1 & $4^{\dagger}$ & 1 & 1 & 9 & 11 \\
\hline 7. Unfamiliar speaker on phone & 0 & 4 & $6^{\dagger}$ & 3 & 5 & 18 & 6 \\
\hline 8. Hearing phone ring from another room & 1 & $3^{\dagger}$ & 2 & 2 & 2 & 10 & 10 \\
\hline 9. Hear front door bell or knock & 0 & 1 & 2 & 2 & $12^{\dagger}$ & 17 & 7 \\
\hline 10. Hear traffic & 0 & 0 & 2 & 1 & $3^{\dagger}$ & 6 & 13 \\
\hline 11. Increased social contact & 2 & 0 & 1 & $4^{\dagger}$ & 1 & 8 & 12 \\
\hline 12. Feel embarrassed or stupid & 1 & 0 & $6^{\dagger}$ & 2 & 0 & 9 & 11 \\
\hline 13. Feeling left out & 1 & $4^{\dagger}$ & 2 & 3 & 1 & 11 & 9 \\
\hline 14. Feeling upset or angry & 1 & 0 & 1 & 1 & $2^{\dagger}$ & 5 & 14 \\
\hline 15. Church or meeting & $5^{\dagger}$ & 3 & 1 & 3 & 3 & 15 & 8 \\
\hline 16. Other & 0 & 0 & 1 & $3^{\dagger}$ & 1 & 5 & 14 \\
\hline Total & 50 & 49 & 50 & 49 & 43 & 243 & \\
\hline
\end{tabular}

${ }^{\dagger}$ The first category of each column

Table 5. Average scores and correlation coefficient between test and retest of Korean-Client Oriented Scale of Improvement

\begin{tabular}{|c|c|c|c|c|c|c|}
\hline \multirow{2}{*}{ Subscale } & \multirow{2}{*}{ Item } & \multicolumn{2}{|c|}{ Test } & \multicolumn{2}{|c|}{ Retest } & \multirow{2}{*}{ Correlation coefficient } \\
\hline & & Mean & $\mathrm{SD}$ & Mean & SD & \\
\hline \multirow[t]{5}{*}{ Improvement } & Q1-1 & 3.67 & 0.49 & 3.93 & 0.46 & $0.40^{*}$ \\
\hline & Q2-1 & 3.27 & 0.70 & 3.60 & 0.51 & \\
\hline & Q3-1 & 3.33 & 0.90 & 3.40 & 0.74 & \\
\hline & Q4-1 & 3.00 & 0.85 & 3.47 & 0.64 & \\
\hline & Q5-1 & 3.67 & 1.18 & 3.87 & 0.64 & \\
\hline \multicolumn{2}{|c|}{ Total } & 3.39 & 0.87 & 3.65 & 0.63 & \\
\hline \multirow[t]{5}{*}{ Final ability } & Q1-2 & 3.40 & 0.51 & 3.60 & 0.51 & $0.45^{*}$ \\
\hline & Q2-2 & 3.13 & 0.83 & 3.53 & 0.64 & \\
\hline & Q3-2 & 3.13 & 0.74 & 3.13 & 0.83 & \\
\hline & Q4-2 & 2.87 & 0.92 & 3.20 & 0.77 & \\
\hline & Q5-2 & 3.53 & 1.25 & 3.87 & 0.80 & \\
\hline \multicolumn{2}{|c|}{ Total } & 3.21 & 0.89 & 3.44 & 0.74 & \\
\hline
\end{tabular}

${ }^{*} p<0.01$. SD: standard deviation 
Table 6. Average scores and values of Cronbach's alpha of Korean-International Outcome Inventory for Hearing Aids items

\begin{tabular}{|c|c|c|c|c|c|c|}
\hline Measure & Item & Mean & SD & Number of selection of score 5 & Number of selection of score 1 & Cronbach's alpha \\
\hline \multirow[t]{4}{*}{ Factor 1} & Q1 & 4.46 & 0.76 & 31 & 0 & 0.32 \\
\hline & Q2 & 3.46 & 0.81 & 5 & 0 & 0.65 \\
\hline & Q4 & 3.72 & 0.88 & 9 & 0 & 0.60 \\
\hline & Q7 & 3.64 & 0.88 & 9 & 0 & 0.58 \\
\hline \multicolumn{2}{|c|}{ Total } & 3.82 & 0.63 & 54 & 0 & 0.76 \\
\hline \multirow[t]{3}{*}{ Factor 2} & Q3 & 3.52 & 0.74 & 2 & 0 & 0.63 \\
\hline & Q5 & 3.54 & 1.27 & 9 & 4 & 0.13 \\
\hline & Q6 & 3.80 & 0.90 & 12 & 0 & 0.20 \\
\hline \multicolumn{2}{|c|}{ Total } & 3.64 & 0.61 & 23 & 4 & 0.22 \\
\hline
\end{tabular}

SD: standard deviation
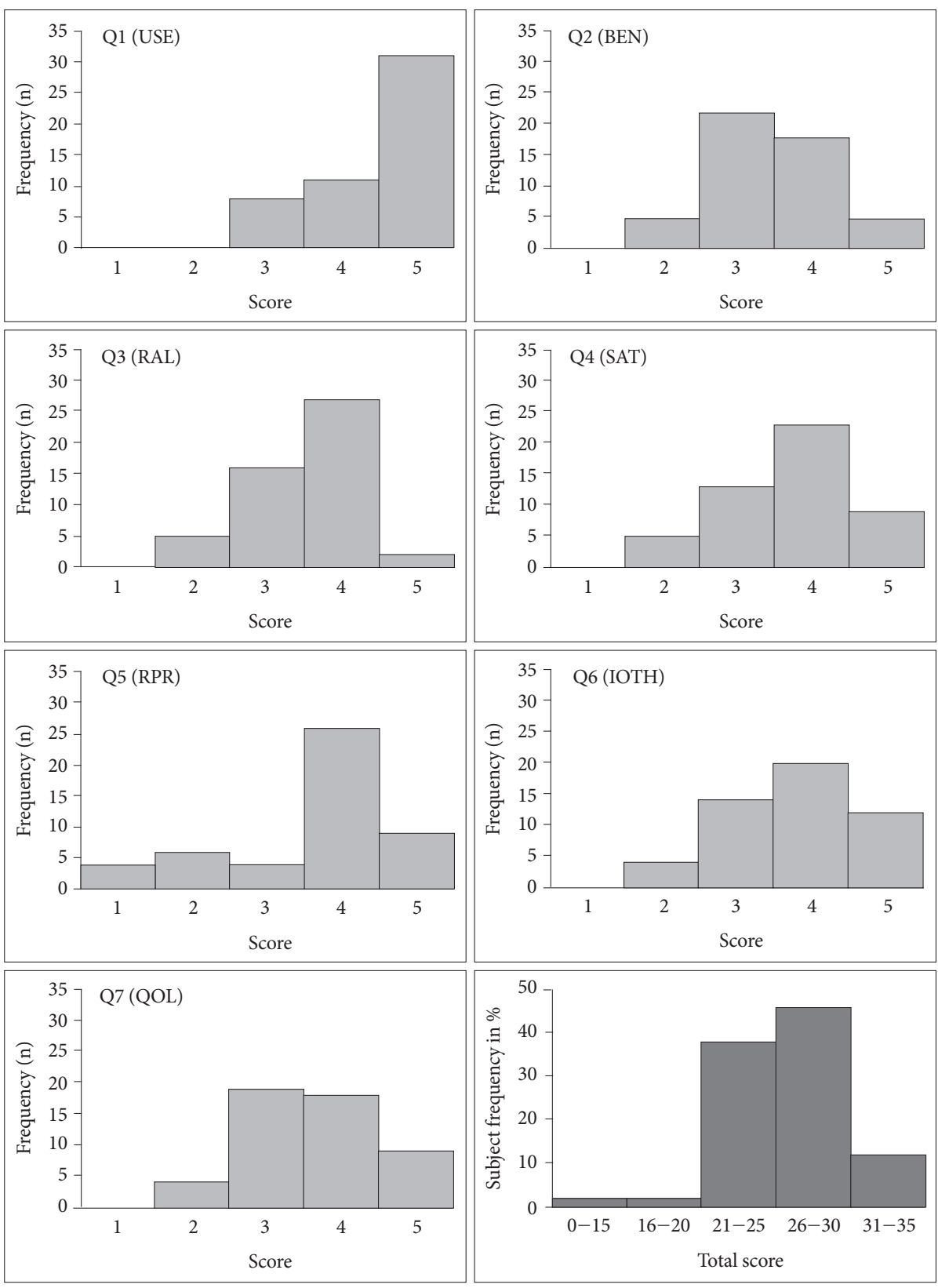

Figure 2. Distribution of scores of Korean-International Outcome Inventory for Hearing Aids for each item and total score. USE: daily use, BEN: benefit, RAL: residual activity limitations, SAT: satisfaction, RPR: residual participation restrictions, IOTH: impact on others, QOL: quality of life. 
Table 7. Inter-correlation among the questions

\begin{tabular}{clllllll}
\hline Item & 1 (USE) & $2(\mathrm{BEN})$ & $3(\mathrm{RAL})$ & $4(\mathrm{SAT})$ & $5(\mathrm{RPR})$ & $6(\mathrm{IOTH})$ & $7(\mathrm{QOL})$ \\
\hline 1 & 1 & & & & & & \\
2 & $0.31^{*}$ & 1 & $0.55^{* *}$ & 1 & & & \\
3 & 0.11 & $0.61^{* *}$ & $0.61^{* *}$ & 1 & & \\
4 & 0.26 & 0.15 & 0.15 & -0.26 & 1 & 1 \\
5 & $0.50^{* *}$ & 0.21 & $0.31^{*}$ & 0.18 & -0.08 & $0.42^{*}$ \\
6 & -0.19 & $0.58^{* *}$ & $0.58^{* *}$ & $0.71^{* *}$ & -0.10 & 1 \\
7 & 0.10 & 0.10 & & & & \\
\hline
\end{tabular}

${ }^{*} p<0.01,{ }^{* *} p<0.05$. USE: daily use, BEN: benefit, RAL: residual activity limitations, SAT: satisfaction, RPR: residual participation restrictions, IOTH: impact on others, QOL: quality of life

Table 8. Average scores and correlation coefficient between test and retest of Korean-International Outcome Inventory for Hearing Aids

\begin{tabular}{|c|c|c|c|c|c|c|}
\hline \multirow{2}{*}{ Subscale } & \multirow{2}{*}{ Item } & \multicolumn{2}{|c|}{ Test } & \multicolumn{2}{|c|}{ Retest } & \multirow{2}{*}{ Correlation coefficient } \\
\hline & & Mean & $\mathrm{SD}$ & Mean & $\mathrm{SD}$ & \\
\hline \multirow[t]{4}{*}{ Factor 1} & Q1 (USE) & 4.67 & 0.72 & 4.93 & 0.26 & $0.80^{*}$ \\
\hline & Q2 (BEN) & 3.33 & 0.62 & 3.93 & 0.46 & \\
\hline & Q4 (SAT) & 3.73 & 0.70 & 3.93 & 0.70 & \\
\hline & Q7 (QOL) & 3.73 & 0.70 & 3.80 & 0.77 & \\
\hline \multicolumn{2}{|c|}{ Total } & 3.87 & 0.34 & 4.15 & 0.31 & \\
\hline \multirow[t]{3}{*}{ Factor 2} & Q3 (RAL) & 3.27 & 0.70 & 3.13 & 0.83 & 0.47 \\
\hline & Q5 (RPR) & 3.40 & 1.40 & 3.53 & 0.92 & \\
\hline & Q6 (IOTH) & 3.93 & 0.96 & 4.00 & 0.65 & \\
\hline \multicolumn{2}{|c|}{ Total } & 3.53 & 0.60 & 3.56 & 0.53 & \\
\hline
\end{tabular}

${ }^{*} p<0.01$. SD: standard deviation, USE: daily use, BEN: benefit, SAT: satisfaction, QOL: quality of life, RAL: residual activity limitations, RPR: residual participation restrictions, IOTH: impact on others

'RPR'로 보청기 착용 시 사회적 참여의 방해 정도는 매우 적은 것으로 나타났다.

문항에 따른 점수 분포를 나타낸 그래프를 분석할 때, 1 번 문항인 'USE'에 대하여 31명이 '8시간 이상'을 선택하여 긍정적 인 답변이 가장 많이 나타난 문항으로 분석되었다. 2 번 문항인 'BEN'에 대하여 '보통으로 도움이 되었다'는 답변이 22명으로 가장 많았고, 3번 문항인 'RAL'에 대하여 '조금 어려웠다'는 답 변이 27명으로 가장 많았다. 4번 문항인 ‘SAT'에 대한 답변은 '꽤 많이 가치 있다고 선택한 경우가 23명으로 가장 많았다. 5 번 문항인 'RPR'에 대한 답변에는 '조금 방해된다'고 응답한 경 우가 26명으로 가장 많았고, 6번 문항인 'IOTH'에 대한 답변에 는 '조금 불편하다’고 응답한 경우가 20명으로 가장 많았고, 7 번 문항인 'QOL'에 대한 답변에는 '조금 더 즐겁게 한다'고 응 답한 경우가 19명으로 가장 많았다(Figure 2).

각 문항에 따른 상관관계를 살펴보면 1 번 문항은 2 번과 5 번, 2 번 문항은 3, 4, 7번, 3번 문항은 4, 6, 7번, 4번 문항은 7번, 6 번 문항은 7번 문항과 유의미한 상관관계를 보였지만 5 번 문항은 다른 문항들과 의미 있는 상관관계가 나타나지 않았다(Table 7).

$\mathrm{K}-\mathrm{IOI}-\mathrm{HA}$ 의 검사-재검사의 상관계수는 0.74 이고 '보청기 착 용 후 만족 요인'과 ‘보청기 착용 후 제한 요인'에서 모두 양의 상
Table 9. Correlation coefficient among three questionnaires

\begin{tabular}{lccc}
\hline & K-SADL & K-COSI & K-IOI-HA \\
\hline K-SADL & 1 & & \\
K-COSI & $0.72^{*}$ & 1 & \\
K-IOI-HA & $0.56^{*}$ & $0.42^{*}$ & 1 \\
\hline
\end{tabular}

${ }^{*} p<0.01$. K-SADL: Korean-Satisfaction with Amplification in Daily Life, K-COSI: Korean-Client Oriented Scale of Improvement, K-IOIHA: Korean-International Outcome Inventory for Hearing Aids

관관계로 신뢰도가 높은 것으로 나타났다(Table 8).

\section{설문지 간 비교 분석}

세 개의 보청기 만족도 설문지를 평균점수와 백분율로 환산 하여 비교분석하였을 때, 세 설문지에 대한 평균점수와 백분율 은 $\mathrm{K}-\mathrm{SADL}$ 은 4.76점과 $67.9 \%, \mathrm{~K}$-COSI는 3.60점과 $72.0 \%, \mathrm{~K}-$ $\mathrm{IOI}-\mathrm{HA}$ 는 3.73점과 $74.7 \%$ 로 나타났다. 반복 측정된 일원배치 분산분석 결과 세 설문지 간 유의미한 차이를 보였다 $[\mathrm{F}(2,147)$ $=5.23, p<0.05]$.

Pearson 상관분석으로 세 설문지에 대한 상관관계를 분석한 결과 $\mathrm{K}-\mathrm{SADL}$ 과 $\mathrm{K}-\mathrm{COSI}$ 는 0.72 의 유의미한 양의 상관관계 $(p<0.05)$ 를, $\mathrm{K}-\mathrm{SADL}$ 과 $\mathrm{K}-\mathrm{IOI}-\mathrm{HA}$ 는 0.56 의 유의미한 양의 상관관계 $(p<0.05)$ 를, $\mathrm{K}-\mathrm{COSI}$ 는 $\mathrm{K}-\mathrm{IOI}-\mathrm{HA}$ 와 0.42 의 유의미 
Table 10. Correlations between K-IOI-HA items and K-COSI measures (Kendall's tau)

\begin{tabular}{lcllcccc}
\hline \multirow{2}{*}{ K-COSI measures } & \multicolumn{7}{c}{ K-IOI-HA items } \\
\cline { 2 - 8 } & Q1 & Q2 & Q3 & Q4 & Q5 & Q6 & Q7 \\
\hline Overall improvement & 0.08 & $0.37^{* *}$ & $0.35^{* *}$ & $0.33^{* *}$ & -0.05 & $0.36^{* *}$ & $0.40^{* *}$ \\
Overall final ability & -0.15 & $0.28^{*}$ & $0.32^{*}$ & $0.27^{*}$ & -0.18 & $0.49^{* *}$ & $0.41^{* *}$ \\
First improvement & 0.20 & $0.38^{* *}$ & 0.23 & $0.40^{* *}$ & 0.03 & 0.19 & $0.29^{*}$ \\
First final ability & 0.03 & $0.30^{*}$ & 0.11 & 0.24 & 0 & 0.16 & 0.22 \\
\hline
\end{tabular}

${ }^{*} p<0.01,{ }^{* *} p<0.05$. K-IOI-HA: Korean-International Outcome Inventory for Hearing Aids, K-COSI: Korean-Client Oriented Scale of Improvement

Table 11. Correlations between $\mathrm{K}-\mathrm{COSI}$ measures and $\mathrm{K}-\mathrm{IOI}-\mathrm{HA}$ factors (Kendall's tau)

\begin{tabular}{lcc}
\hline & K-COSI improvement & K-COSI final ability \\
\hline K-IOI-HA factor 1 & $0.56^{* *}$ & $0.39^{*}$ \\
K-IOI-HA factor 2 & $0.35^{*}$ & 0.26 \\
\hline
\end{tabular}

${ }^{*} p<0.01,{ }^{* *} p<0.05$. K-COSI: Korean-Client Oriented Scale of Improvement, K-IOI-HA: Korean-International Outcome Inventory for Hearing Aids

한 양의 상관관계 $(p<0.05)$ 를 보여 세 설문지 모두 서로 유의 미한 상관관계를 보였다(Table 9).

세 개의 설문지 중 유사한 보청기의 만족도 범위를 검사하는 $\mathrm{K}-\mathrm{IOI}-\mathrm{HA}$ 와 $\mathrm{K}-\mathrm{COSI}$ 설문지의 검사 결과를 비교하여 보았다. 범주별 상관관계를 분석하면 $\mathrm{K}-\mathrm{IOI}-\mathrm{HA}$ 는 각 문항이 거의 한 개의 범주를 대표하기 때문에 각 문항과 $\mathrm{K}-\mathrm{COSI}$ 의 두 개 범주 와 비교할 때, 전반적인 점수와 $\mathrm{K}-\mathrm{IOI}-\mathrm{HA}$ 의 2, 3, 4, 6, 7번 문 항 점수가 유의미한 상관관계를 보였다. 또한 $\mathrm{K}-\mathrm{COSI}$ 의 '첫 번 째 청력 향상의 정도(first improvement)'는 $\mathrm{K}-\mathrm{IOI}-\mathrm{HA}$ 의 2, 4, 7번 문항과 유의미한 상관관계를 보였고, '첫 번째 최종적 청력 변화(first final ability)'는 $\mathrm{K}-\mathrm{IOI}-\mathrm{HA}$ 의 상관관계는 $\mathrm{K}-\mathrm{COSI}$ 의 2 번 문항과 각각 유의미한 상관관계를 보였다. $\mathrm{K}-\mathrm{IOI}-\mathrm{HA}$ 의 5 번 문항은 $\mathrm{K}-\mathrm{COSI}$ 의 어떠한 범주에서도 유의미한 상관관계 를 보이지 않았다(Table 10).

$\mathrm{K}-\mathrm{IOI}-\mathrm{HA}$ 와 $\mathrm{K}-\mathrm{COSI}$ 의 두 범주 간 상관관계를 분석한 결 과, factor 1 은 $\mathrm{K}-\mathrm{COSI}$ 의 두 측정 범주인 '전체적인 청력 향상 정도'와 ‘보청기 착용 후 최종적 청력 변화’와 유의미한 상관관 계를 보였고 factor 2 는 '전체적인 청력 향상 정도'와 유의미한 상관관계를 보였지만 “보청기 착용 후 최종적 청력 변화’와 유의 미한 상관관계를 보이지 않았다(Table 11).

\section{보청기 유형 및 착용 방법에 따른 분석}

보청기 유형에 따른 $\mathrm{K}-\mathrm{SADL}$ 의 평균점수는 ITC는 4.33점, $\mathrm{CIC}$ 는 5.08점, $\mathrm{RIC}$ 는 4.79점이었고 $[\mathrm{F}(2,47)=2.56, p>0.05]$, $\mathrm{K}-\mathrm{COSI}$ 의 평균점수는 ITC는 3.37점, $\mathrm{CIC}$ 는 3.79점, $\mathrm{RIC}$ 는 3.61점 $[\mathrm{F}(2,47)=1.53, p>0.05], \mathrm{K}-\mathrm{IOI}-\mathrm{HA}$ 의 평균점수는 ITC는 3.81점, $\mathrm{CIC}$ 는 3.64점, $\mathrm{RIC}$ 는 3.74점 $[\mathrm{F}(2,47)=0.28, p>$ 0.05]으로 세 설문지 모두 유의미한 차이를 보이지 않았다. 또한

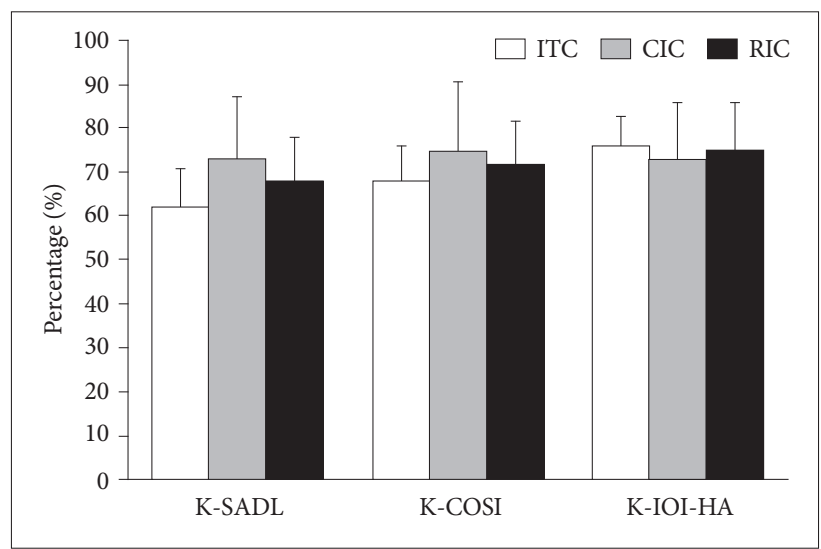

Figure 3. Comparison of three hearing aid types in three satisfaction questionnaires. ITC: In The Canal, CIC: Completely In the Canal, RIC: Receiver In the Canal, K-SADL: Korean-Satisfaction with Amplification in Daily Life, K-COSI: Korean-Client Oriented Scale of Improvement, K-IOI-HA: Korean-International Outcome Inventory for Hearing Aids.

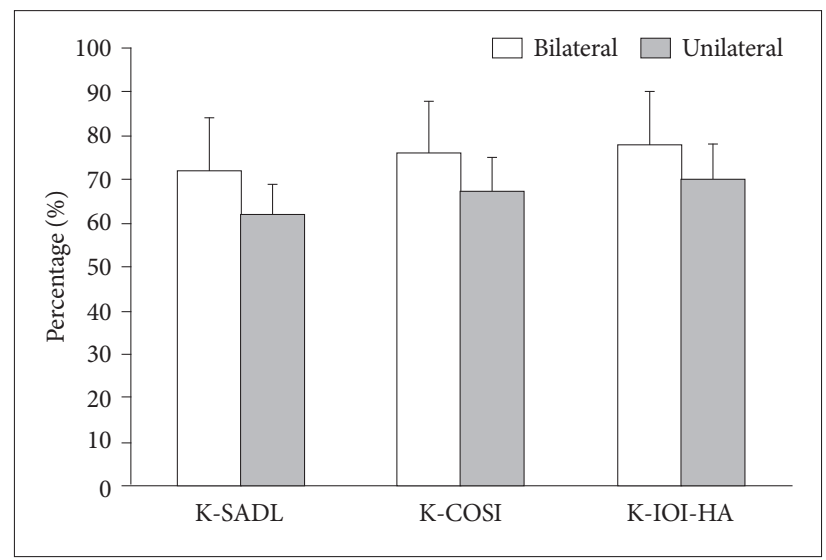

Figure 4. Comparison between bilateral and unilateral hearing aids in three satisfaction questionnaires. K-SADL: Korean-Satisfaction with Amplification in Daily Life, K-COSI: Korean-Client Oriented Scale of Improvement, K-IOI-HA: Korean-International Outcome Inventory for Hearing Aids.

세 가지 보청기 유형별로 분석하였을 때, $68 \%, 74 \%, 72 \%$ 의 만 족도를 보였고 유의미한 차이를 보이지 않았다 $[\mathrm{F}(2,47)=0.85$, $p>0.05]$ (Figure 3). 구체적으로 살펴보면, $\mathrm{K}-\mathrm{SADL}$ 과 $\mathrm{K}-$ $\mathrm{COSI}$ 평가에서 $\mathrm{CIC}$ 착용자들의 만족도가 상대적으로 높았고 $\mathrm{K}-\mathrm{IOI}-\mathrm{HA}$ 는 ITC와 RIC 착용자의 만족도가 조금 더 높았으 
나 큰 차이는 없었다.

보청기 만족도를 보청기 착용 방법에 따라 분석하였을 때, 편측과 양측의 각 설문지 만족도 평균점수는 $\mathrm{K}-\mathrm{SADL}$ 은 4.36 점과 5.03점 $[\mathrm{F}(1,48)=10.03, p<0.05]$ 으로, $\mathrm{K}-\mathrm{COSI}$ 는 3.33점 과 3.78점 $[\mathrm{F}(1,48)=9.01, p<0.05]$ 으로, $\mathrm{K}-\mathrm{IOI}-\mathrm{HA}$ 는 3.52점과 3.88 점 $[\mathrm{F}(1,48)=5.97, p<0.05]$ 으로 모두 양측 착용자에서 더 만족도가 높은 점수를 보였으며 유의미한 차이가 나타났다. 세 개 설문지를 통합하여 분석하였을 때도 양측 보청기 착용자 가 더 높은 보청기 사용 만족도를 보이는 것으로 나타났다 $[\mathrm{F}(1$, 48) $=12.36, p<0.05$ ] (Figure 4).

\section{DISCUSSIONS}

K-SADL의 내적 일관성을 확인하기 위해 크론바흐 알파 값 을 분석한 본 연구 결과는 0.83 으로 선행연구의 0.82 와 매우 유 사한 수준으로 나타났다(Cox \& Alexander, 2001). 또한 검사재검사의 상관관계도 0.83 으로 선행연구들의 결과인 0.81 과 매 우 유사한 것으로 나타났다(Cox \& Alexander, 1999; Cox \& Alexander, 2001). 또한 영역별 본 연구와 원저자들의 연구의 평균점수는 '긍정적 효과' 영역에서 0.75 점과 0.77점, '부정적 측 면' 영역에서 0.64 점과 0.65 점, '서비스 및 비용적 측면' 영역에서 0.55점과 0.61점, '개인적 이미지' 영역에서 0.29점과 0.66점으로 세 개의 범주에서는 거의 유사한 점수를 보였으나 '개인적 이미 지'에서는 평균점수가 원논문보다 매우 낮게 나타났다(Cox \& Alexander, 2001). 그 원인으로는 보장구 착용에 대한 정서·문 화적 차이로 인한 느낌이나 해당 범주의 문항 해석의 차이로도 생각될 수 있다.

K-COSI의 내적 일관성을 확인하기 위해 크론바흐 알파 값 을 분석한 본 연구 결과는 0.83 으로 나타나 선행연구의 0.76 0.83과 유사하게 나타났다(Dillon et al., 1997). 또한 본 연구 결과와 원저자들의 범주별 평균점수는 '전체적인 청력 향상의 정도'에서 3.61점과 4.47점, '보청기 착용 후 최종적 청력 변화'에 서 3.58점과 4.45점, 검사-재검사 상관관계는 0.40 과 0.37 , 그리 고 0.45 와 0.84 로 원저자들의 설문지가 본 연구보다 높은 평균 점수와 높은 상관관계를 보였다(Dillon et al., 1999). 이러한 원 인으로 대상자의 차이를 생각해 볼 수 있다. 왜냐하면 선행연 구에서 보청기 신규 착용자와 기존 착용자를 비교하여, 신규 착용자 그룹에서 유의미하게 낮은 만족도 점수가 나타나는 경 향을 보고하고 있기 때문이다(Dillon et al., 1999). 본 연구의 대상자는 모두 보청기 신규 착용자여서 낮은 평균점수가 나타 난 것으로 생각된다. 또한 상황을 설명하는 언어와 문화적 차 이도 하나의 원인으로 생각되는데, 설문지의 특성이 매우 주관 적인 상황을 설명하는 경우 해석, 문화적 정서, 대상자 등에 따
라 차이가 있기 때문으로 생각된다. 듣기 상황 선택에 영향을 주는 요소로 대상자의 연령을 생각해 볼 수 있다. 본 연구의 대 상자는 60대 미만이 6명으로 $12 \%, 60$ 대 이후는 44명으로 $88 \%$ 였고, 평균 연령은 74세였다. 본 연구에서 가장 많이 선택한 두 가지 상황은 '보통 크기의 TV 혹은 라디오 듣기 상황'과 '조용 한 곳에서 한두 명과 대화 상황으로 가정 내에서 생활하는 시 간이 많고 배우자나 자녀들과 원활한 의사소통을 원하는 노년 층의 기대가 반영된 것으로 생각할 수 있다. 이는 연구 대상자 의 평균 연령이 76 세인 원저자들의 연구 결과에서 나타난 순위 와 동일하여(Dillon et al., 1999), 두 연구가 공통적으로 노년층 의 의견이 반영된 것으로 생각할 수 있다. 또한 문항이 제시되 는 순서가 답변에 영향을 주는 것으로 나타났는데, 본 연구의 답변 $1,2,3$ 순위가 각각 $1,3,5$ 번 문항으로 나타나서 그러한 가능성을 시사하였다.

$\mathrm{K}-\mathrm{IOI}-\mathrm{HA}$ 의 내적 일관성을 확인하기 위해 크론바흐 알파 값을 분석한, 본 연구 결과는 0.7 로 원저자들의 연구 결과인 0.75 , 덴마크의 연구 결과인 0.82 , 포르투갈의 연구 결과인 0.84 , 스웨덴의 연구 결과인 $0.81,2005$ 년의 K-IOI-HA의 선행 연구인 0.83 보다 다소 낮게 나타났으나 위의 모든 연구에서 일 반적으로 양호한 내적 일관성을 보여주는 범위로 해석할 수 있 다(Arlinger et al., 2017; Chu et al., 2012; Cox \& Alexander, 2002; Lee et al., 2005; Pavia et al., 2017; Thunberg Jespersen, 2014). 검사-재검사의 상관관계는 본 연구에서 전체 영역은 0.74 이고, factor 1 에서 0.80 , factor 2 에서 0.47 로 제한 요인인 factor 2에서 낮은 신뢰도를 보였다. 이는 유럽의 연구 결과들 과 유사한데, 네덜란드와 덴마크의 factor 1 의 상관계수는 각각 0.73 과 0.78 , factor 2 는 $0.62,0.54$ 로 factor 2의 신뢰도가 떨어지 는 경향이 유사하게 나타났다(Kramer et al., 2002; Thunberg Jespersen, 2014). 그러나 영어 원본에서는 factor 2 가 0.84 로 상 관계수가 높게 나타나서 번역본에서만 factor 2 가 낮은 상관관 계를 보이는 것으로 나타나, 이러한 현상도 번역본의 한계점을 시사하는 것으로 생각된다(Cox \& Alexander, 2002). 또 다른 요인인 5 번과 6 번은 모두 보청기 착용 후 지난 2주 동안의 보청 기의 효과를 평가하는 것인데, 재검사는 이후 3 주 뒤에 평가한 결과이므로 검사-재검사 상관계수가 좀 떨어지게 나타난 것으 로 생각된다. 네덜란드에서는 IOI-HA로 2002년에 실시했던 연 구에 비해 2014년에 실시한 연구에서 전반적으로 높은 점수가 나타났는데, 이는 10여 년간 보청기 기술의 발전과 착용 방법에 대한 지속적인 연구, 보청기 상담 및 재활의 증가, 보청기 양측 착용의 보편화 등이 전반적인 보청기 착용 만족도를 향상시킨 것으로도 해석할 수 있다(Kramer et al., 2002; Thunberg Jespersen et al., 2014). 문항별 평균점수의 범위는 본 연구에서는 3.64 4.46점으로 나타났고 네덜란드, 덴마크, 포르투갈, 스웨덴 
선행연구에서는 3.19 4.34점, 3.52 4.59점, 3.19 4.54점, 3.31 4.1점이었고 국내 선행연구에서 평균점수는 3.49 4.41점으로 국 내외의 문항별 평균점수의 범위는 유사하게 나타났다(Arlinger et al., 2017; Kramer et al., 2002; Lee et al., 2005; Pavia et al., 2017; Thunberg Jespersen et al., 2014).

$\mathrm{K}-\mathrm{COSI}$ 와 $\mathrm{K}-\mathrm{IOI}-\mathrm{HA}$ 의 상관성을 분석하였을 때, $\mathrm{K}-\mathrm{IOI}-$ $\mathrm{HA}$ 의 5 번 문항은 K-COSI의 어떠한 범주에서도 유의미한 상 관관계를 보이지 않았는데, 이는 IOI-HA와 COSI를 비교한 선 행연구와 동일한 결과로(Stephens, 2002), 저자들은 이를 보청 기 착용 시 활동이 제한되는 점을 COSI에서는 거의 포함하고 있지 않기 때문일 것으로 설명하였고, 본 연구에서도 동일한 해 석이 적용될 수 있을 것으로 생각된다.

보청기 유형과 착용 형태에 대한 분석에서, 보청기 유형에 따 라 세 설문지의 차이에 통계적인 유의미성이 나타나지 않았지 만 $\mathrm{K}-\mathrm{SADL}$ 과 $\mathrm{K}-\mathrm{COSI}$ 에서는 $\mathrm{CIC}$ 가, $\mathrm{K}-\mathrm{IOI}-\mathrm{HA}$ 에서는 ITC 가 가장 높은 점수를 보인 것으로 확인되었다. 이는 귓속형과 귀걸이형을 큰 보청기로 분류하고 $\mathrm{CIC}$ 와 ITC를 작은 보청기로 분류하여 SADL을 평가하였을 때, 작은 보청기가 큰 보청기에 비해 '개인적 이미지'에서 통계적으로 유의미하게 높은 만족도 를 보였고, 다른 세 가지 영역에서도 통계적인 유의성은 없었으 나 작은 보청기에서 높은 평균점수를 보인 국내 연구 보고와 유사한 결과이다(Lee et al., 2004). RIC의 만족도에 대한 분석 은 본 연구에서는 세 가지 설문지에서 모두 귓속형보다는 높고 고막형보다는 낮은 만족도를 나타냈다. RIC의 만족도는 일반적 으로 외관상의 특성을 제외하고 들리는 말소리의 선명도, 압박 감, 피드백, 전화상의 목소리의 명료도 등에서 통계적으로 유의 미하게 높은 만족도를 보여 일반적으로 RIC의 만족도가 높은 것으로 보고되었다(Otto, 2005). 따라서 우리나라에서는 RIC의 일반적인 만족도보다는 외관이 비교적 더 중시되는 것으로 해 석할 수 있다.

보청기의 편측 착용에 비해 양측 착용자는 소리 위치의 분별 력이 우수하고, 소음 상황 속에서 말소리 인지능력이 향상되어 결과적으로 삶의 질을 높인다고 밝혀진 선행연구들(Gelfand \& Silman, 1993; Shimokura et al., 2013; Silverman et al., 2006) 의 내용과 유사하게 본 연구에서도 편측 착용자보다 양측 착용 자에서 유의미하게 높은 보청기 만족도가 나타났다. 본 연구는 분석에 수집된 참여자의 수가 적었던 점과 연구 참여자의 $88 \%$ 가 60 대 이상인 장 노년층으로 설문 문항을 완벽히 이해하는 데 한계가 있었던 점이 아쉬웠다. 추후 60 대 이하를 포함한 다 양한 연령대의 자료를 더 수집하고 보청기 신규 착용자뿐 아니 라 지속해서 착용해 왔던 기존 보청기 착용자를 포함해서 연구 한다면 보청기 만족도 분석이 더 정교하게 실시될 수 있을 것 으로 생각한다.
각 설문지를 통해 나타난 검사-재검사 상관계수와 내적 일 관성은 $\mathrm{K}-\mathrm{SADL}$ 은 0.83 과 $0.83, \mathrm{~K}-\mathrm{COSI}$ 는 0.71 과 $0.83, \mathrm{~K}-$ IOI-HA는 0.74와 0.70으로 세 설문지 모두 검사-재검사가 신뢰 도도 있고 내적 일관성도 높아 실제 임상에서 무리 없이 사용될 수 있을 것이다. 또한 이 세 개의 설문지들을 보완적으로 사용함 으로써 보청기 만족도 평가의 범위를 확대할 수 있을 것으로 생 각된다. 예를 들어, $\mathrm{K}-\mathrm{IOI}-\mathrm{HA}$ 는 검사 소요 시간이 짧고 간단히 요약된 보청기 만족도를 평가하고, K-SADL로 네 가지 범주를 구분하여 구체적으로 보청기 만족도를 평가하고, $\mathrm{K}-\mathrm{COSI}$ 로 현 실적인 활용도가 높은 상황의 만족도를 평가할 수 있다. 본 번역 본을 제작하면서 자문을 구했던 임상 경력 5년 이상의 청능사 들은 K-COSI가 보청기 착용자의 주관적 관점을 다양한 상황 에 따라 효율적으로 분석하여 적절한 조치를 제공할 수 있고 보청기 및 인공와우의 재활 전후에 사용하여 보장구의 효과를 검증하기 위한 분석 도구로도 유용하다고 의견을 제시하였다. 따라서 보청기 만족도를 평가하는 목적과 활용하고자 하는 방 법에 따라 세 가지 설문지를 다르게 적용하거나 종합적인 보청 기 만족도를 평가하고자 할 때는 세 가지 설문지를 모두 활용 하면 좋을 것으로 생각된다. 이러한 분석을 통해 국내에서 보청 기 만족도 평가의 범위를 확대하고 보청기 만족도의 실태를 정 확하게 확인하여 보청기를 재피팅하고, 재활 계획을 구체적으 로 수립하고, 재활 결과를 평가하여 보청기 만족도를 증가시킬 수 있는 설문지 자료로 활용하고자 한다. 궁극적으로 국내 보청 기 착용자의 만족도에 대한 폭넓고 체계적인 평가를 통해 보청 기 착용에 대한 불편 요소를 확인하고 개선하여 국내 보청기 만족도를 향상시키고자 한다. 향후 대상자 수를 증가하여 경도, 중도, 고도의 난청 정도에 따른 보청기 만족도 비교를 한다면 더 유용성이 높은 보청기 만족도 결과를 얻을 수 있을 것으로 생각한다.

중심 단어 : 설문지· $\mathrm{K}-\mathrm{SADL} \cdot \mathrm{K}-\mathrm{COSI} \cdot \mathrm{K}-\mathrm{IOI}-\mathrm{HA} \cdot$ 보청기 만족도.

\section{Ethical Statement}

The entire procedure including participant recruitment, testing, compensation, and data handling followed the protocol approved by the Institutional Review Board of the Hallym University (HIRB-2017-126).

\section{Acknowledgments}

The authors thank to the participants for their time; Myungsook Won, Dongchang Kim, Suyeon Shin, Sung Il Park, Dongwook Yoo, Ki-Do Lee, and Han Dong Ryu for their assistance in participants recruitment and data collection. The agreements of interpretation for the questionnaires from Robyn M. Cox and Harvey Dillon were appreciated.

\section{Declaration of Conflicting Interests}

There are no conflict interests. 


\section{Funding}

This work was supported by Ministry of Education and Science Technology, Brain Korea 21 Plus, R\&D Center for Auditory-Speech Rehabilitation Program, 22B20130011070.

\section{REFERENCES}

Arlinger, S., Nordqvist, P., \& Öberg, M. (2017). International Outcome Inventory for Hearing Aids: Data from a large Swedish quality register database. American Journal of Audiology, 26(3S), 443-450.

Chu, H., Cho, Y. S., Park, S. N., Byun, J. Y., Shin, J. E., Han, G. C., et al. (2012). Standardization for a Korean adaptation of the International Outcome Inventory for Hearing Aids: Study of validity and reliability. Korean Journal of Otorhinolaryngology-Head and Neck Surgery, 55(1), 20-25.

Cox, R. M. \& Alexander, G. C. (1995). The abbreviated profile of hearing aid benefit. Ear and Hearing, 16(2), 176-186.

Cox, R. M. \& Alexander, G. C. (1999). Measuring satisfaction with amplification in daily life: The SADL scale. Ear and Hearing, 20(4), 306-320

Cox, R. M. \& Alexander, G. C. (2001). Validation of the SADL questionnaire. Ear and Hearing, 22(2), 151-160.

Cox, R. M. \& Alexander, G. C. (2002). The International Outcome Inventory for Hearing Aids (IOI-HA): Psychometric properties of the English version: El Inventario International de Resultados para Auxiliares Auditivos (IOI-HA): Propiedades psicometricas de la version en ingles. International Journal of Audiology, 41(1), 30-35.

Cox, R. M. \& Gilmore, C. (1990). Development of the Profile of Hearing Aid Performance (PHAP). Journal of Speech Language and Hearing Research, 33(2), 343-357.

Cox, R. M., Gilmore, C., \& Alexander, G. C. (1991) Comparison of two questionnaires for patient assessed hearing aid benefit. Journal of the American Academy of Audiolology, 2(3), 134-145.

Dillon, H., Birtles, G., \& Lovegrove, R. (1999). Measuring the outcomes of a national rehabilitation program: Normative data for the Client Oriented Scale of Improvement (COSI) and the Hearing Aid User's Questionnaire (HAUQ). Journal of the American Academy of Audiology, 10(2), 67-79.

Dillon, H., James, A., \& Ginis, J. (1997). Client Oriented Scale of Improvement (COSI) and its relationship to several other measures of benefit and satisfaction provided by hearing aids. Journal of the American Academy of Audiology, 8(1), 27-43.

Gatehouse, S. \& Noble, W. (2004). The Speech, Spatial and Qualities of Hearing Scale (SSQ). International Journal of Audiology, 43(2), 85-99.

Gelfand, S. A. \& Silman, S. (1993). Apparent auditory deprivation in children: Implications of monaural versus binaural amplification. Journal of the American Academy of Audiology, 4(5), 313-318.

Han, W., Lee, D., Koo, M., \& Kim, J. (2015). Questionnaires for the hearingimpaired adults and elderly: A systematic literature review. Audiology and Speech Research, 11(1), 3-16.

Heo, J. H. \& Lee, J. H. (2009). Binaural benefit on K-HINT score for adults who use CI and HA. Audiology and Speech Research, 5(1), 60-70.

Korea Institute for Health and Social Affairs. (2014). 2014 National Survey for Persons with Disabilities (2014-73). Seoul: Ministry of Health and Welfare.

Korea Institute for Health and Social Affairs. (2017). 2016 National Survey for Persons with Disabilities (2016-73). Seoul: Ministry of Health and Welfare.

Korean Ministry of Employment and Labor. (2015). 2015 Employment and Labor Policy in Korea. Seongnam: EDI Publications.

Kramer, S. E., Goverts, S. T., Dreschler, W. A., Boymans, M., \& Festen, J. M.
(2002). International Outcome Inventory for Hearing Aids (IOI-HA): Results from the Netherlands: El Inventario Internacional de Resultados para Auxiliares Auditivos (IOI-HA): Resultados en los Países Bajos. International Journal of Audiology, 41(1), 36-41.

Ku, H. L. \& Kim, J. S. (2010). The Development of the Korean Evaluation Scale for Hearing Handicap (KESHH) for the geriatric hearing loss. Journal of the Korean Gerontological Society, 30(3), 973-992

Lee, I. Y., Byun, J. Y., Kim, H., Chang, M. K., Cho, J. S., \& Cha, C. I. (2004). The application of the satisfaction with amplification in daily life scale in hearing aid users. Korean Journal of Otorhinolaryngology-Head and Neck Surgery, 47(12), 1217-1223.

Lee, M. A., Kim, J. S., \& Ahn, J. H. (2005). International Outcome Inventory for Hearing Aids (IOI-HA) Korean version. Korean Journal of Audiology, 9(1), 65-76.

Ministry of Health and Welfare. (2009). 2008 Disability Status. Sejong: Ministry of Health and Welfare.

Newman, C. W., Weinstein, B. E., Jacobson, G. P., \& Hug, G. A. (1990). The Hearing Handicap Inventory for Adults: Psychometric adequacy and audiometric correlates. Ear and hearing, 11(6), 430-433.

Noh, H. I. (2007). Rehabilitation for the elderly or presbycusis using hearing aids. Korean Journal of Otorhinolaryngology-Head and Neck Surgery, 50(10), 846-853.

Otto, W, C. (2005). Evaluation of an open-canal hearing aid by experienced users. The Hearing Journal, 58(8), 26, 30, 32.

Paiva, S. M., Simões, J. F., Paiva, A. M., Sousa, F. J., \& Bébéar, J. P. (2017). Translation of the International Outcome Inventory for Hearing Aids into Portuguese from Portugal. BMJ Open, 7(3), e013784.

Purdy, S. C. \& Jerram, J. C. (1998). Investigation of the profile of hearing aid performance in experienced hearing aid users. Ear and Hearing, 19(6), $473-480$.

Saunders, G. H. \& Cienkowski, K. M. (1996). Refinement and psychometric evaluation of the attitudes toward Loss of Hearing Questionnaire. Ear and Hearing, 17(6), 505-519.

Shimokura, R., Hosoi, H., Iwakura, T., Nishimura, T., \& Matsui, T. (2013). Development of monaural and binaural behind-the-ear cartilage conduction hearing aids. Applied Acoustics, 74(11), 1234-1240.

Shin, E. Y. (2011). A model study of aural rehabilitation program for presbycusis through the analyses of Korean standardized values of the hearing handicap (Unpublished doctoral dissertation). Hallym Univerisity, Chuncheon.

Silverman, C. A., Silman, S., Emmer, M. B., Schoepflin, J. R., \& Lutolf, J. J. (2006). Auditory deprivation in adults with asymmetric, sensorineural hearing impairment. Journal of the American Academy of Audiolo$g y, 17(10), 747-762$.

Stephens, D. (2002). The International Outcome Inventory for Hearing Aids (IOI-HA) and its relationship to the Client-Oriented Scale of Improvement (COSI): El Inventario Internacional de Resultados para Auxiliares Auditivos (IOI-HA) y su relatiócute; n con la Escala de Mejoría Orientada hacia el Cliente (COSI). International Journal of Audiology, 41(1), $42-47$.

Thunberg Jespersen, C., Bille, M., \& Legarth, J. V. (2014). Psychometric properties of a revised Danish translation of the International Outcome Inventory for Hearing Aids (IOI-HA). International Journal of Audiology, 53(5), 302-308.

Ventry, I. M. \& Weinstein, B. E. (1982). The hearing handicap inventory for the elderly: A new tool. Ear and hearing, 3(3), 128-134.

Yun, D. H., Yoon, T. H., \& Lee, K. S. (2000). Subjective satisfaction in hearing aid users by APHAB. Korean Journal of Otorhinolaryngology-Head and Neck Surgery, 43(7), 698-702. 


\section{APPENDICES}

\section{Appendix 1. Korean-International Outcome Inventory for Hearing Aids}

국제 표준 보청기 효과 지수

1. 지난 2주 동안 현재 사용하고 있는 보청기를 얼마나 사용하셨는지 생각해 보십시오. 하루에 평균 몇 시간 정도 보청기를 사용하 셨습니까?

$\begin{array}{lllll}\text { 전혀 사용하지 않았다 } & \text { 1시간 이하 } & \text { 1 4시간 } & \text { 4 8시간 } & \text { 8시간 이상 }\end{array}$

2. 현재의 보청기를 착용하기 전에 더 잘 듣고 싶었던 상황을 생각해 보십시오. 지난 2주 동안 현재의 보청기가 그 상황에서 얼마나 도움이 되었습니까?

$\begin{array}{ccccc}\text { 전혀 도움되지 } & \text { 조금 도움이 } & \text { 보통으로 도움이 } & \text { 꽤 많이 도움이 } & \text { 아주 많이 도움이 } \\ \text { 않았다 } & \text { 되었다 } & \text { 되었다 } & \text { 되었다 } & \text { 되었다 }\end{array}$

3. 특히 더 잘 듣고 싶었던 상황을 다시 생각해 보십시오. 현재의 보청기를 사용할 때 그러한 상황에서 아직도 얼마나 어려우십니까? 아주 많이 어렵다 꽤 많이 어렵다 보통으로 어렵다 조금 어렵다 전혀 어려움이 없다

4. 모든 것을 고려할 때, 현재의 보청기가 사용할 만한 가치가 있다고 생각하십니까?
전혀 가치가 없다
조금 가치 있다
보통으로 가치 있다
꽤 많이 가치 있다
아주 많이 가치 있다

5. 지난 2주 동안 현재의 보청기를 착용한 상태에서, 난청이 당신이 하고자 하시는 일에 얼마나 방해가 됩니까?

아주 많이 방해된다 꽤 많이 방해된다 보통으로 방해된다 조금 방해된다 전혀 방해되지 않는다

6. 지난 2주 동안에 현재의 보청기를 착용한 상태에서, 다른 사람들이 당신의 난청 때문에 얼마나 불편해 합니까?

아주 많이 불편해 한다 꽤 많이 불편해 한다 보통으로 불편해 한다 조금 불편해 한다 전혀 불편해 하지 않는다

7. 모든 것을 고려할 때, 현재의 보청기가 당신의 인생을 얼마나 더 즐겁게 합니까?

더 우울하게 한다 변화 없다 조금 더 즐겁게 한다 꽤 즐겁게 한다 아주 많이 즐겁게 한다

Korean version of International Outcome Inventory for Hearing Aids (IOI-HA) translated by Jinsook Kim 
Appendix 2. Korean-Satisfaction with Amplification in Daily Life

KOREAN-SATISFACTION WITH AMPLIFICATION IN DAILY LIFE (K-SADL)

성명

생년월일

검사일자

다음의 문항들은 사용하시는 보청기에 대한 의견을 묻는 질문입니다. 각각의 문항에 가장 알 맞은 답을 찾아 “ $\bigcirc$ ”로 표시해 주시길 바랍니다. “ $\square$ ”의 오른쪽 목록은 답으로 표시할 각 알 파벳에 대한 의미입니다.

당신의 답변은 현재 사용하고 있거나, 가장 최근까지 사용했던 보청기에 대한 의견이라는 것 을 명심해 주시길 바라며 신중하게 답변해 주십시오.
A 전혀 그렇지 않다
$B$ 약간 그렇다
C 다소 그렇다
D 보통은 그렇다
$\mathrm{E}$ 상당히 그렇다
$F$ 매우 그렇다
$\mathrm{G}$ 전적으로 그렇다

1. 보청기를 착용하면 자주 대화하던 사람의 말을 이해하는 데 도움이 됩니까?

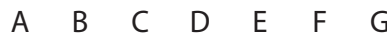

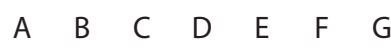

2. 보청기가 주변 잡음을 증폭시켜 당신이 듣고 싶은 말소리를 방해할 때, 당신은 실망스럽습니까?

3. 보청기 구입이 당신의 최대 관심사 중 하나였습니까?

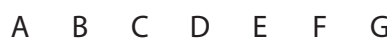

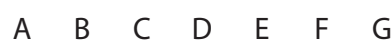

4. 보청기를 착용하면, 주변 사람들이 당신의 청력손실을 더 잘 알아차릴 것이라고 생각하십니까?

5. 보청기를 착용하면 다른 사람 말을 못 알아들어 되묻는 횟수가 감소하였습니까?

6. 보청기는 사용할 만한 가치가 있다고 생각하십니까?

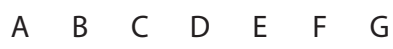

7. 보청기 사용 중, “삐 ” 소리 때문에 볼륨을 충분히 높일 수 없어서 불편하십니까?

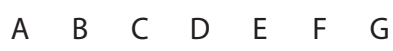

8. 보청기 외형에 대해서 당신은 만족하십니까?

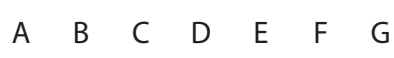

9. 보청기 착용이 자신감을 더 증가시켰습니까?

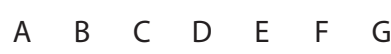

10. 보청기를 통한 소리가 자연스럽게 들리십니까?

11. 대부분의 전화통화에서 보청기가 얼마나 도움이 된다고 생각하십니가?

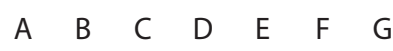

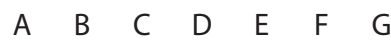

(보청기를 사용하지 않고도 전화통화를 잘 하시면 여기에 체크하세요 $\square$ )

12. 당신에게 보청기를 제공한 사람은 전문적 지식이 충분하였습니까?

13. 보청기 착용이 당신을 약간 능력이 떨어지는 사람처럼 보이게 만든다고 생각하십니까?

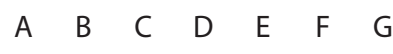

14. 보청기 가격은 적당하다고 생각하십니까?

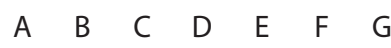

15. 보청기의 내구성(고장이 나서 수리를 필요로 하는 횟수의 정도)은 어느 정도

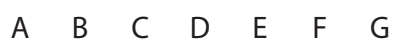

마음이 드십니까?

A $B \quad C \quad D \quad E \quad F \quad G$ 
아래의 항목들도 답변해 주십시오.

\begin{tabular}{|c|c|c|c|}
\hline $\begin{array}{c}\text { 현재 착용 중인 보청기의 } \\
\text { 사용 기간 }\end{array}$ & \begin{tabular}{|c} 
현재까지 전 생애를 통해 \\
보청기를 사용한 총 기간 \\
(이전에 사용하셨거나 현재 착용하는 \\
보청기 모두 포함한 기간)
\end{tabular} & $\begin{array}{c}\text { 하루 평균 보청기 } \\
\text { 사용 시간 }\end{array}$ & $\begin{array}{c}\text { 난청의 정도 } \\
\text { (보청기를 착용하지 않은 } \\
\text { 상태 기준) }\end{array}$ \\
\hline $\begin{array}{l}\square \text { 6주 미만 } \\
\square \text { 6주에서 11개월 } \\
\square \text { 1년에서 10년 } \\
\square \text { 10년 이상 }\end{array}$ & $\begin{array}{l}\square \text { 6주 미만 } \\
\square \text { 6주에서 11개월 } \\
\square \text { 1년에서 10년 } \\
\square \text { 10년 이상 }\end{array}$ & $\begin{array}{l}\square \text { 전혀 사용하지 않는다 } \\
\square \text { 하루 중 1시간 미만 } \\
\square \text { 하루 중 1시간에서 4시간 } \\
\square \text { 하루 중 4시간에서 8시간 } \\
\square \text { 하루 중 8시간에서 16시간 }\end{array}$ & $\begin{array}{l}\square \text { 정상 청력 } \\
\square \text { 경도 } \\
\square \text { 중도 } \\
\square \text { 고도 }\end{array}$ \\
\hline
\end{tabular}

수고하셨습니다. 음영으로 된 부분은 전문가가 기록하는 곳이니 답변하지 않으셔도 됩니다.

\section{FOR AUDIOLOGISTS USE ONLY}

HEARING AND FITTING:

Right Ear

Make

Model

Ser. No.

Fitting Date

Style: CIC ITC LTE BTE
Left Ear

Make

Model

Ser. No.

Fitting Date

HEARING AID FEATURES (적용되는 곳에 모두 체크하세요)

$\square$ Directional Microphone

$\square$ Peak clipping

Style: $\mathrm{CIC}$

ITC LTE BTE

$\square$ Multiple Microphones

$\square$ Compression limiting

Multi-channel

$\square$ TILL

$\square$ Remote Control

$\square$ WDRC

Multi-program

$\square$ BILL

$\square$ No volume control

$\square$ T-Coil 
G Kim et al.

ASR

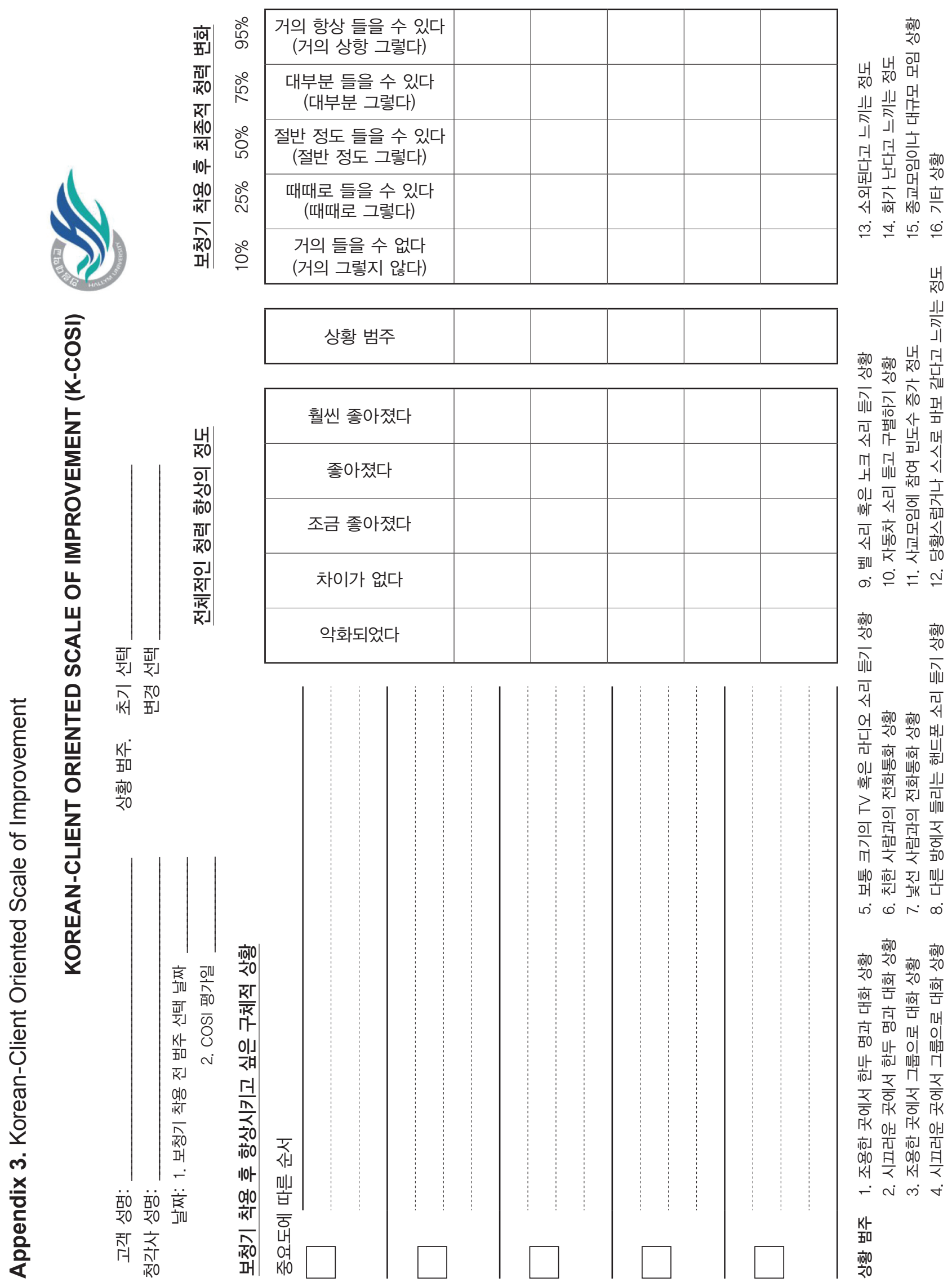

